\title{
Knowledge and Technology Transfer Influencing the Process of Innovation in Green Supply Chain Management: A Multicriteria Model Based on the DEMATEL Method
}

\author{
Marcela Marçal Alves Pinto *D, João Luiz Kovaleski, Rui Tadashi Yoshino and \\ Regina Negri Pagani (iD) \\ Department of Industrial Engineering, Federal University of Technology, Paraná (UTFPR), \\ 84016-210 Ponta Grossa, Brazil; kovaleski@utfpr.edu.br (J.L.K.); ruiyoshino@utfpr.edu.br (R.T.Y.); \\ reginapagani@utfpr.edu.br (R.N.P.) \\ * Correspondence: mar_marcal@hotmail.com
}

Received: 17 April 2019; Accepted: 31 May 2019; Published: 25 June 2019

check for updates

\begin{abstract}
After performing a systematic review of the literature, it was noticeable that the discussion regarding Green Supply Chain Management (GSCM) along with Knowledge and Technology Transfer (KTT) and Innovation is scarce. To address this issue, the objective of this paper is to analyze the relationship between GSCM, KTT, and Innovation. To achieve this purpose, we developed a conceptual framework based on the literature review, which raised some hypotheses. In order to verify the hypotheses and validate the framework, we designed a multicriteria model called the KTT-GSCM Multicriteria Model, composed of two stages. The first stage describes factors that are relevant to GSCM, KTT, and Innovation, ascertaining which ones have influence over the others and which ones are influenced by the others, through the Decision-Making Trial and Evaluation Laboratory (DEMATEL) method. The second stage of the model analyzes the level of each perspective in each company and in the supply chain as a whole, thus verifying the hypotheses. This model was applied in 13 firms of a supply chain that has a rotomolding firm as a focal company. Through the development and application of the model, it was possible to verify the hypotheses raised and conclude that the perspectives of GSCM, KTT, and Innovation are, in fact, influenced by one another and that both Innovation and KTT promote greater development in GSCM.
\end{abstract}

Keywords: green supply chain management; knowledge and technology transfer; innovation; multicriteria model; DEMATEL; conceptual framework

\section{Introduction}

A strategic way of addressing the global context of new production trends is based on the adoption of the best managerial practices regarding supply chains (SCs), addressing sustainability issues [1]. Green supply chains (GSCs) are formed so that all of the involved parts achieve a sustainable competitive advantage [2].

GSCM can be defined as 'the sum of green purchasing [3], green manufacturing, green materials management, green distribution and marketing, green reverse logistics [4], green product design [5], and green collaboration with customers [6-8]. The 'green' in GSCM indicates the effect that the SC has on the environment [6]. According to Srivastava [5], the scope of GSCM ranges from the reactive monitoring of general environmental management programs to more proactive practices implemented through various Rs (Reduce, Re-use, Rework, Refurbish, Reclaim, Recycle, Remanufacture, Reverse logistics, etc.). Sarkis et al. [4] defines GSCM as the integration of environmental concerns into 
inter-organizational practices. GSCM aims to adopt a life cycle method (i.e., product design, material selection, manufacturing, and sales and recovery) to maximize overall environmental profit [9], which helps the organization to achieve its ecological growth and development [10]. According to Lam et al. [11], GSCM exposes "the applications of the most important sustainable development issues demonstrates how green technologies and practices can be implemented and, in line with this, the motivation of saving money and increasing efficiency".

There are many concepts of GSCM, which are not new. However, there is no clear and perfect policy for GSCM implementation in organizations [12]. To improve the performance of GSCM implementation, a set of reasonable and viable measures need to be proposed and prioritized in a systematic way [13].

Many advanced practices of environmental management require the integration of different actors in the SC system. Integration usually requires the construction of information sharing and knowledge transfer networks between manufacturers, suppliers, and customers. Interactive information networks with mutual trust between the organizations reflect the strength of Knowledge and Technology Transfer (KTT). KTT processes with customers and other stakeholders allow firms to achieve sustainable business goals [14], sustainable environmental goals [15,16], and sustainable social goals [17]. With high levels of information sharing, the firms in a SC are able to plan long-term partnerships to improve their performances [18].

Seuring and Müller [19] considered that both product- and process-related innovations might be observable. Based on a new strategic positioning, companies can introduce innovations applied to products and processes, creating opportunities to access new markets, to improve their image, and to obtain competitive advantages [20-22].

A firm's capability to innovate technologically is highly dependent on the development speed of a new product or on the adoption of recent technological innovation on its processes. Innovative features are crucial for its survival and sustainability. Muduli et al. [23] empirically confirmed that a firm's technological innovation can improve the performance of GSCM practices. Successful innovations require research and development, knowledge capital, improved materials, and other resources. In other words, KTT is fundamental for innovation to occur. The basic concept of the KTT process is the movement of technology or knowledge from one place to another $[24,25]$.

In the literature, several studies confirm the relationship between GSCM and Innovation [19,23,26-33]. Other studies have investigated the relationship between GSCM and KTT [5,18,34-36], and many other studies can be categorized under the label of KTT and Innovation [37-47]. However, after performing the systematic literature review, it was noticeable that no research has explored the relationship between these three approaches together (i.e., green supply chain, KTT and Innovation) and the influence on one another (Section 3.1-Table 1).

GSCM, KTT and Innovation have been extensively investigated, but mainly treated as separate research streams, which has resulted in these subject fields being separately and independently researched from each other. This suggests the existence of a gap in our current understanding of the relationship between these three perspectives. Joining all these subjects together in a way that it could make sense is the originality of this research, and a contribution to the literature In addition, the lack of a clear relationship between these perspectives is an obstacle for companies seeking to justify the implementation of GSCs.

Therefore, considering the context presented, the objective of this paper is to analyze the relationship between GSCM, KTT, and Innovation. In order to achieve this purpose, we developed a conceptual framework based on a systematic review of the literature, which raised three hypotheses. In order to verify the hypotheses and validate the framework, we designed a model composed of two stages, called the KTT-GSCM Multicriteria Model. The first stage describes factors that are relevant to GSCM, KTT and Innovation, describing the relation of influence that the factors have on one another, through the Decision-Making Trial and Evaluation Laboratory (DEMATEL) method. The second stage 
of the model analyzes the level of each perspective for each company and the level of each perspective in the chain as a whole, thus verifying the hypotheses.

The model was applied in a SC that has a rotomolding firm as a focal company. The chain features 13 supplier companies (four business-to-business [B2B] companies, and nine business-to-consumer [B2C] companies).

This study presents significant theoretical and practical contributions:

1. First, a systematic review of the literature that generated a conceptual framework to study the relationship between different elements of interest for the academia and companies as well, namely, GSCM, KTT and Innovation.

2. Second, the KTT-GSCM Multicriteria Model, which analyzes the directions of influence between GSCM, KTT and Innovation.

3. Third, the confirmation proposed in the literature that GSCM, KTT and Innovation have a direct relationship. Nevertheless, such a relationship has not been assessed in the scholarly literature and this is important in clarifying the role of the three perspectives regarding their effect on GSCs.

4. Finally, the companies that are studied will benefit from this instrument, since it allows a broader view of the factors that influence others, as well as how their green management, KTT and Innovation stands before their suppliers, customers and competitors.

This paper is organized as follows. This section contextualizes the theme of the research, presents the problem and objectives, and the structure of the paper. Section 2 describes the conceptual framework that was designed by the literature review, and the hypotheses generated from it. Section 3 describes the methodology used in this study (Systematic Literature Review and the development of the KTT-GSCM Multicriteria Model). Section 4 presents the case used to apply the proposed model. Section 5 presents the complete application of the model. The results are presented and discussed in Section 6. Finally, a conclusion of this study is provided in Section 7 .

\section{Conceptual Framework and Hypotheses}

To address the gap identified in the literature, this paper proposes a conceptual framework for the development of GSCM through Knowledge and Technology Transfer (Figures 1 and 2). This conceptual framework establishes the interconnection between GSCM, Innovation and KTT, and presents a SC with green aspects. In order to optimize efficiency, aspects of KTT are interlinked.

The framework contains a complete process of analysis based on the SCOR model [48]. The Supply Chain Operational Reference (SCOR) model, developed by the Supply Chain Council (SCC), provides a structure to characterize the practices and processes of SC management that result in best-in-class performances. The model was designed to help firms acquire knowledge regarding the internal and external processes of their fields [49]. The SCOR model, in version 11.0, is based on six central processes of management: plan, source, make, deliver, return and enable.

Based on the SCOR model, the conceptual framework presents these six central management processes, along with some KTT mechanisms: R\&D, support from universities/research centers, consulting services, the acquisition of products from third parties, and the purchase of ready technologies. The green factors were also added to the SCOR model. It means that, for each of the six SCOR model processes, the green focus is inserted.

The GreenSCOR extension of the model was first introduced in its fifth version. Cheng et al. [50] and Schoeman and Sanchez [51] note that GreenSCOR is a modification that integrates environmental considerations through processes, metrics and best practices into SCM processes, while taking into account the impacts of operations on each stage of the product life cycle [52]. 


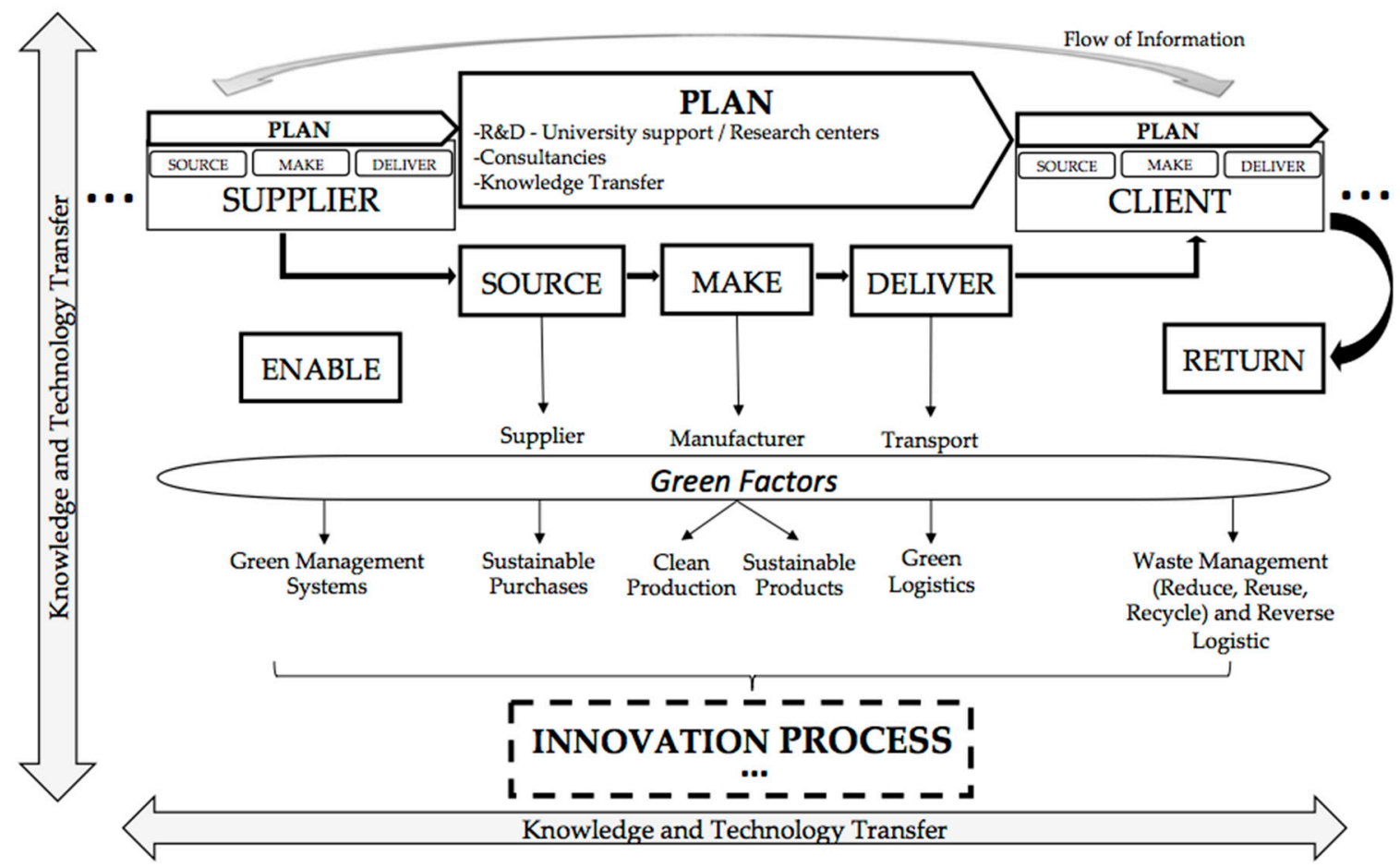

Figure 1. Conceptual framework for the development of Green Supply Chain Management (GSCM) through Knowledge and Technology Transfer (KTT).

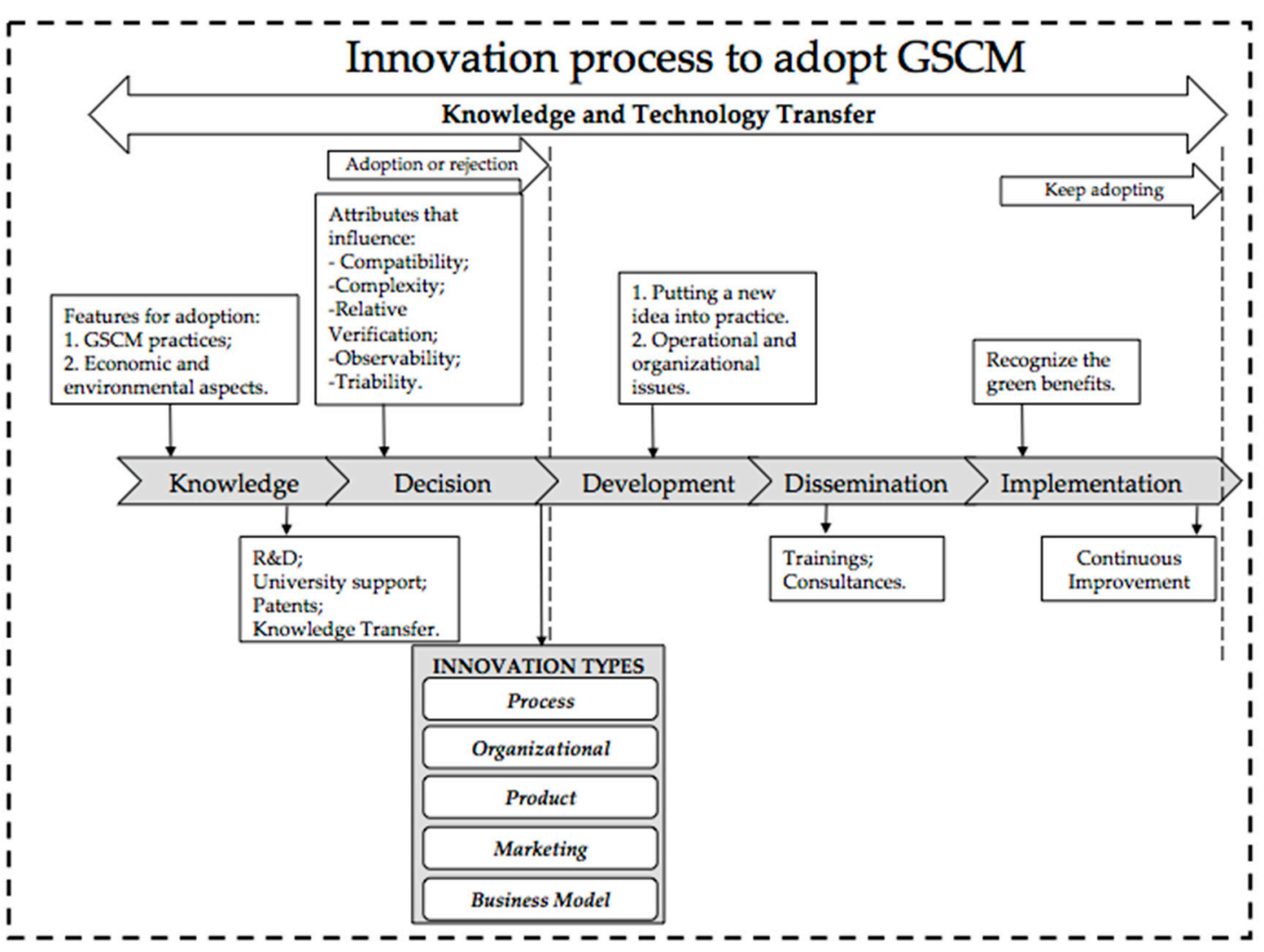

Figure 2. Conceptual framework for the development of GSCM through Technology Transfer (TT) Innovation. 
GSCM not only incorporates environmental philosophy into the business, but also ensures the sustainable growth of industries [53,54]. The evaluation of sustainability involves environment and ethical or social problems [55]. The triple bottom line (TBL) perspective of sustainability differentiates social, environmental and economic performance dimensions. According to this perspective, sustainability can be achieved at the intersection of these three dimensions. Therefore, organizations should strive to perform well on the three dimensions of the TBL [56].

The GSCM determinants (Green Marketing; Green Design; Green Purchasing; Green Manufacturing; Green Distribution; Green Reverse Logistics; Green Management System) are supposed to develop a relation of interdependency in a way to develop an analytical network structure with the system [57]. Therefore, they were added to the SCOR model (Figure 1).

The development of green planning is required to operate the SC, i.e., environmental training, ISO orientations, sustainable action planning, sustainable product planning and commitment of employees to environmental protection programs [58]. Green Marketing and Green Design are included in the planning of the GSCM (Plan). Green marketing refers to the use of 'green' in an environmental context during marketing and promoting products and services [59]. A great number of organizations believe that green design plays a major role in the cost reduction of the process because it is more efficient than traditional design procedures to reduce the environmental burden [60].

Sustainable Purchases/Green Purchasing (Source) refer to the acquisition of goods and services that have lower impact on the environment than other products or services that meet similar requisites [61]. The selection of partners in the supply chain should also be based on ecological guidelines [58].

The manufacturer, after acquiring products from third parties through sustainable purchases, must, in turn, focus on two aspects: clean production and the production of sustainable products (Make). In order to achieve this purpose, there must be innovation in the organization, in the process, in the production, and in every actor of the SC. Then, Green manufacturing should emphasize reducing parts, rationalizing materials and reusing components, which help in making products that are more efficient to build [62].

After the production stage, the firm needs to deliver its product to the client. This next stage of the GSC involves Green logistics/Green Distribution (Deliver).

In order to ensure the efficacy of a GSC, clients must also participate and be aware of their role in continuing the green actions or strategies (Return). After the final consumption of the product by customers, there is the return of what remained: damaged or non-conforming products, packages, bottles, or other residues. At this stage, waste management, which may be defined as Reducing, Reusing, and Recycling Products, and Reverse Logistics [58], comes into action. Cost savings and enhanced competitiveness can be achieved by properly managing wastes in green marketing similarly to reverse logistics and waste exchange [63].

In order to enable the whole process to develop with greater efficiency, you need Planning and an efficient Management of the entire GSC (Enable). The green management system controls the corporation's activity, and it is mostly concerned with the efforts of the administration, its measures and the involvement of the organization in the environmental management [64]. Thus, GSCM involves not only cooperating with suppliers, but also with recipients, other stakeholders and managers so as to shape the relations between these systems $[65,66]$. Buyer-supplier relationships help to develop and enhance coordination and collaboration between GSCM associates [57]. In addition, GSCM is also understood as responsible by the management of material, information and capital flows, by the means of cooperation between companies throughout the supply chain [4].

KTT is present in every stage of the SC, occurring between its actors and also within a single organization, aiming to develop new techniques and opportunities for the effective management of environmental impacts. Throughout the SC, there is a bidirectional information flow in which all information, knowledge, material and capital is shared with the other stages in the process.

In order to increase the efficiency of the supply chain, members of the chain should manage the logistics and storing of these flows jointly. Alternatively, they hand these functions over to other 
members. The effective flow of products within the SC can be well achieved concerning the adaptation of the production, logistics, and marketing of the products, as well as other related activities [58].

According to Kot [58], the flow of information is equally essential for business success, and it includes information concerning the order and status of the products delivered. For that purpose, information technology (IT) tools are used to create effective communication amongst the members of the supply chain. The flow of resources includes financial aspects (payments, credit rules, or the instrument of ownership) and non-financial aspects (people and equipment), and both improve the effectiveness of the supply chain [58].

The impacts of KTT on SC performance depend on the types and methods of knowledge sharing. If new information is able to access each nodule of the SC, its efficiency and efficacy can be enhanced, accelerating information flow [35].

Adopting GSCM requires Innovation (Figure 2). Green and Sustainable innovation can be defined as new or modified processes, techniques, practices, systems and products to reduce social and environmental harm $[67,68]$. Recycling, waste management, green efficiency, and green design are essentially concerned with reducing the environmental and social impact of organizational products. These aspects should also be considered in organizational sustainability innovations [69]. Greater innovations occur with the support of R\&D and KTT $[23,70]$. This process is presented in five parts, based on the frameworks of So et al. [61], ATTC [71] and Klewitz and Hansen [72].

The first part is Knowledge, which encompasses the acquisition of the knowledge required to comprehend GSCM, its practices, and the environmental and economic aspects. Support from universities, R\&D, patents, and knowledge sharing are TT mechanisms also presented in this stage.

The second part is the Decision, and the decision on whether the innovation will be adopted or rejected is made. For an innovation to occur, some barriers need to be broken. One of them, often regarded as the largest, is the resistance of change.

The third part, Development, involves operational and organizational matters that may arise when putting the new idea into practice.

Dissemination, the fourth part, raises awareness about an innovation in order to facilitate its adoption and implementation. Dissemination strategies include raising awareness, building knowledge, and distributing materials [71]. In this stage, KTT mechanisms of training and consulting services are strongly present.

Finally, the fifth part corresponds to the Implementation. It is a complex and dynamic process that involves incorporating a practical innovation to the routine.

Knowledge derived from innovation is required in GSCM. According to Carvalho and Barbieri [73], and Gmelin and Seuring [74], sustainable innovation is the introduction of products, production processes, management practices, business methods, marketing, new or significantly improved, that bring economic, social, and environmental outcomes. Thus, there are five types of innovation:

- Process innovation is related to the production of goods and services, and often has the goal of improving eco-efficiency. It is even more distinctive in end-of-pipe solutions and cleaner production technologies. It may alter the way to utilize resources, manage product outputs through closed-loop production schemes or industrial symbiosis, and it improves the global eco-efficiency of business operations [72];

- Organizational innovation involves the reorganization of routines and structures within the firm and new management styles. It also includes management systems that are more formalized, such as environmental management systems [72];

- Product innovation consists of enhancing or developing completely new products and services. For instance, eco-design may enhance products through ecologically correct materials, high durability, and low energy consumption, whereas the development of sustainable technologies (for instance, renewable energy technologies) corresponds to entirely new products [72]; 
- Marketing innovation aims to connect with customers and consumers on new and different levels and may include new types of promotional efforts. Thus, a marketing innovation serves to drive demand by creating awareness, brand recognition, and product uniqueness [75];

- Business model innovation is an outcome that changes the industry. Three main types of business model innovation, which can be used alone or in combination, are industry model innovation, revenue model innovation, and enterprise model innovation [76].

These three types of innovation are required to achieve an effective GSC.

KTT is present throughout the entire innovation process of establishing GSCM. It is a multidimensional process that intentionally promotes the use of innovation. Starting from the first stage, knowledge, it continues through the other stages until the implementation. This process requires several interested parties and resources, involving activities related to the translation and adoption of innovations. Therefore, technology transfer must be designed to accelerate the diffusion of an innovation [71].

Based on the literature and on this conceptual framework, some hypotheses were found and presented in the sequence.

\subsection{Hypotheses of GSCM, KTT and Innovation}

\subsubsection{Relationship between GSCM and KTT}

Zhu and Sarkis [77] revealed that firms were able to improve their environmental and economical performances through information exchange and knowledge transfer in external GSCM practices. Luthra et al. [78] stated that KTT to vendors/suppliers is necessary to achieve the objective of environmentally friendly practices.

Within the social complexity, many advanced environmental management practices, such as environmental design and reverse logistics management, all require the integration of different stakeholders from the supply chain system [2]. The management of these integrations normally requires constructing networks concerning information and knowledge sharing among manufacturers, suppliers and customers. The interactive information networks based on mutual trust among the organizations reflect the strength of knowledge transfer, and its potential benefits would reduce the risks of information asymmetry among SC partners. With high levels of information sharing, SC partners build long-term and joint-planning partnership to improve their performances [18].

According to Ravi and Shankar [79], Information Technology (IT) resources have been observed as a very important factor to introduce and implement GSCM in any organization. The information communication and knowledge exchange based on environmentally friendly requirements among manufacturers is a critical success factor of GSCM [35].

$\mathrm{Wu}$ et al. [35] studied the implementation of green supply chain in firms of the IT industry in Taiwan. The objective was to explore constructs of knowledge transfer and the relationships between knowledge transfer and green management performance. The result showed that firms should pursue the effect of short-term costs and benefits of knowledge transfer in order to enhance green management performance. In addition, the authors state that firms in the SCM share information with their partners in order to decrease the incidence of supply chain risks.

Some studies show that two main barriers to GSCM implementation are lack of understanding among the involved actors $[80,81]$, and lack of adequate training $[82,83]$. Both barriers are factors related to KTT. Agi and Nishant [84] state that the implementation of GSCM practices is affected by employee training and education. Training and education are the prime requirements for achieving the successful implementation of GSCM in any organization $[79,85,86]$. Training programs for both employees and suppliers help disseminate information and knowledge about the company's sustainability determination [87].

Thus, managing knowledge is deemed to be critical to achieve a sustainable competitive edge in SC. Knowledge management (KM) transforms information, data and intellectual assets to firms' 
perdurable value through recognizing useful knowledge for running and managing operations. Hence, KM is a decisive attribute in GSCM and increasingly considered as an important source of sustainable competitive advantage [88]. Rao [63] concluded that the knowledge extension level had a positive significant relationship with environmental performance of firms from the greening practices of suppliers.

According to Holland [89], in order to improve interorganizational coordination and product quality, manufacturing firms often demand that their supply chain partners, such as subcontractors or suppliers, implement common processes, which generally requires sharing process knowledge. Therefore, interorganizational knowledge sharing within a supply chain has become a common practice since it enhances the competitive advantage of the supply chain as a whole.

Green manufacturing firms and their supply chain partners are enthusiastic about developing environmentally friendly activities in order to maintain and promote their competitiveness. Due to the on-going development of green technologies and regulations, sharing green experience and up-to-date knowledge between manufacturing firms and their supply chain partners has become imperative [34]. Interorganizational knowledge sharing in GSCM involves activities of transferring or disseminating green knowledge from green manufacturing firms to their partners seeking to develop new capabilities for effective actions. In order to achieve the benefits of interorganizational knowledge sharing, it is essential that all parties involved engage in cooperative relationships [90]. Through effective knowledge sharing, the strategic intent of interorganizational collaborations for a sustainable competitive advantage can be achieved by combining the relevant organizational resources and capabilities of all parties [91].

Srivastava [5] strongly recommended that further research is required on the inter- or intra-organizational activities of best practices, advanced technology transfer or improvement and environmental performance measurement.

Following the previous considerations, the following hypotheses were proposed:

Hypothesis 1a. Knowledge Transfer (KT) has positive effects on GSCM performance.

Hypothesis 1b. Technology Transfer (TT) has positive effects on GSCM performance.

\subsubsection{Relationship between GSCM and Innovation}

Several scholars have analyzed the link between GSCM, green technologies and innovation, and their influence on competitiveness and performance improvement. Consequently, innovations and, particularly, green innovations, seem to point to a more productive and conscious management that aims also to balance the costs needed to make an organization environmentally friendly. This result can be achieved due to an innovative approach to business and resources management, which is often based on specific techniques and technologies, which purpose is to social and ecological conditions [26].

Scholars have also pointed out that sustainability is one of the main areas in which organizational and technological innovations take place, contributing to: lower costs, reducing the used inputs; generating additional revenues due to better products; and, new business creation [26]. Thus, firms can develop innovative strategies for addressing and improving sustainability within their manufacturing processes and supply chains $[19,92,93]$.

Pioneer companies in green innovations profit first from the advantage [78,94]. Early initiatives allow them to develop new markets, gaining competitive advantages and commanding higher prices for green products [29]. When firms seamlessly integrate suppliers and customers, they strengthen their green innovation capabilities [31,95-97]. Moreover, GSCM can be seen as an environmentally sustainable technological innovation [27] that is applied to products design and manufacturing processes [98,99]. 
Innovation complying with environmental regulations can improve product consistency and quality, reducing product costs and improving resource productivity $[28,29]$. Thus, it implies that green innovation is certainly needed in the implementation of GSCM practices in order to achieve company's environmental objectives andincreasing the company's value. There is strategic linkage between GSCM and green innovation in considering the importance of the life cycle of products [96].

Sustainable and green innovation antecedents and characteristics have been studied over the years with a number of findings. According to Horbach [100] and Boons et al. [101], achieving sustainable development requires the implementation of sustainable innovations. Sustainable innovation can be defined as introducing novel, or modifications in, production processes, techniques, systems, organizations and products to reduce environmental damage. Neutzling et al. [102] assume that an effective development of innovation in sustainable SCM strategies relies on the integration of inter-organizational relationships. These are explained by three major factors: (1) resource investments, built on the relational view [90,103]; (2) collaboration [104,105]; and (3) governance mechanisms [106]. These innovations should also provide similar or greater value with improved economic, social and organizational performance [100].

Adams et al. [107] introduced a sustainability-oriented innovation construct that aims to promote changes in processes and products based on clear objectives of creating social and environmental values, while simultaneously generating economic returns. To develop these sustainability-oriented innovations, relevant changes are required in business models. Innovative development also requires new behaviors and relationships with stakeholders along supply chains. The engagement of internal and external stakeholders is important for promoting sustainable innovation in organizations [108].

Sustainable Supply Chains are also associated with certain risks, which need to be addressed through strategies of risk mitigation or through sustainable innovations [109]. When applying sustainable innovations, organizations can benefit in a number of ways (improving its outcomes) which might include cost reduction, thus increasing profits, and improving the organization's social image [110].

According to the diffusion of innovation (DoI) theory, the diffusion of GSCM as an innovation can be viewed as a process of initiation (knowledge), persuasion, planning, adoption, and confirmation [27].

In summary, the literature review indicates that greening the SC has a positive influence on green innovation. In addition, green innovation has a positive impact on competitive advantage [30]. Consequently, the following hypothesis is formulated:

Hypothesis 2. Innovation has a positive effect on GSCM performance.

\subsubsection{Relationship between GSCM, KTT and Innovation}

Sustainability in a supply chain requires new ways of thinking, and the most usual mechanism for implementing novelties and improvements is developing new knowledge and applying it throughout innovations [111].

Innovations are creative ideas generated from individuals or staff, and occur with support from $R \& D$ and through KTT [23]. Drivers for sustainable innovation include strong business networks, seeking to build competitive advantage, R\&D organisational support, cost savings, subsidies and tax cuts, compliance with regulations and customer demand [112].

According to Rogers [39], KTT has been characterized as the adoption of innovation, and the application of technology, techniques or knowledge that has been developed in another organization. It is the application of a technology to a new use or user [113].

Besides, the success of any knowledge transfer may also be affected by the introduction of new and improved ways of doing things at work; that is, by innovation [37,38].

Dubickis and Gaile-Sarkane [40] studied the relationships between innovation and technology transfer and presented a different kind of perspectives: (a) technology transfer includes innovation; 
(b) innovation includes technology transfer; and, (c) innovation and technology transfer overlap. The results confirm the discovered relationships.

The effectiveness of technology transfer depends on the degree of transferred technological knowledge and the recipient company's absorptive capacity in receiving and using the new technology [114]. Technological knowledge transferred can include know-what, know-how, know-why and know-who [115]. The technological knowledge can flow from transferors to transferees through various conventional and unconventional mechanisms, including trade in equipment, foreign direct investment (FDI), joint ventures, licensing agreements, R\&D cooperation, turnkey contracts, outward FDI, as well as international conferences, papers, and labor mobility [116].

Grant [117] claims KTT is a key route for organizations to share and create knowledge, which can foster competitive advantage. The ability to seek and maintain KTT capability facilitates a higher level of innovation [118]. KTT facilitates innovation through problem definition, alternative generation and evaluation, and the ultimate choice of transferred knowledge [119]. R\&D programs and investment subsidies are the first methods introduced to improve performance and stimulate the diffusion of green technology [120].

Broadly speaking, knowledge management and learning have also played important roles in sustainability innovation. Tariq et al. [121] revealed various attributes of sustainable innovation including market factors, stakeholder pressure, technological factors, collaboration and networking, and organizational, social, cultural and ethical factors. All these attributes, as proposed in the extant literature on green innovation, result in economic and financial, market and environmental performance outcomes.

In summary, communication, information sharing, trust and knowledge transfer formed through a strong relationship [122]. Ireland and Webb [123] provide a basis for the development of innovative solutions to environmental challenges [124], thus, improving the environmental performance of the suppliers. Based on the literature findings, we propose the third and last hypothesis:

Hypothesis 3. KTT has a positive influence in the process of Innovation in GSCM.

For better comprehension, Figure 3 presents a scheme of the hypotheses generated.

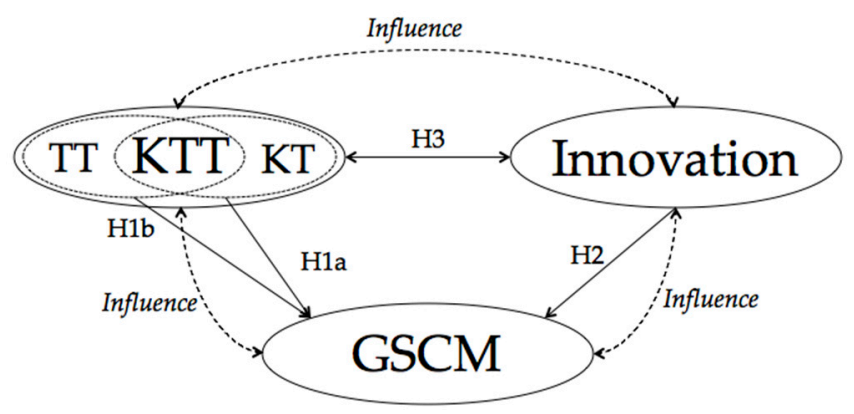

Figure 3. Hypotheses generated.

In the next section, we outline the research design and methodology adopted to construct this conceptual framework and to confirm or refute the hypotheses formulated.

\section{Methodology}

\subsection{Systematic Literature Review}

The systematic literature review used the methodology Methodi Ordinatio, proposed by Pagani et al. [125,126] and adopted in other works [127-129]. The purpose of this methodology is to select articles according to their scientific relevance, taking into account the main factors to be 
considered in a scientific paper: the impact factor of the journal on which the document was published, the number of citations, and the year of publication. The phases of Methodi Ordinatio are:

Phase 1-Establishing the intention of research: 'The relationship between KTT, Innovation and GSCM'.

Phase 2-Preliminary exploratory search with keywords in databases revealed that the databases with a larger amount of works linked to the themes researched were Science Direct, Scopus and Web of Knowledge.

Phase 3-Definition of keyword combinations, as well as bibliographic databases, are presented in Table 1. The temporal delimitation established was from 1990 to 2019, when the concept of GSCM emerged in the literature.

Phase 4-Final search in the databases and gross results are described in Table 1.

Table 1. Protocol for search and collection of papers.

\begin{tabular}{|c|c|c|c|c|c|}
\hline & Keywords and Combinations & $\mathbf{A}$ & B & C & Gross Total \\
\hline 2 & $\begin{array}{l}\text { "Technology Transfer" OR “Knowledge Transfer" } \\
\text { AND "Green Innovation" }\end{array}$ & 3 & 5 & 5 & 13 \\
\hline 4 & $\begin{array}{l}\text { "GSC" OR “Green Supply Chain" AND } \\
\text { "Innovation" OR "Green Innovation" AND } \\
\text { "Technology Transfer" OR "Knowledge Transfer" }\end{array}$ & 0 & 0 & 0 & 0 \\
\hline 5 & $\begin{array}{l}\text { "GSC" OR "Green Supply Chain" AND } \\
\text { "framework" OR "model" }\end{array}$ & $\begin{array}{c}38 \\
\text { (TITLE) }\end{array}$ & $\begin{array}{c}71 \\
\text { (TITLE) }\end{array}$ & $\begin{array}{c}39 \\
\text { (TITLE) }\end{array}$ & 148 \\
\hline 8 & $\begin{array}{l}\text { "GSC" OR “Green Supply Chain" AND } \\
\text { "Innovation" OR “Green Innovation" AND } \\
\text { "model" OR "framework" }\end{array}$ & 13 & 41 & 59 & 113 \\
\hline 9 & $\begin{array}{l}\text { "Technology Transfer" OR “Knowledge Transfer" } \\
\text { AND “Green Innovation" AND "model" OR } \\
\text { "framework" }\end{array}$ & 0 & 2 & 0 & 2 \\
\hline 10 & $\begin{array}{l}\text { "GSC" OR “Green Supply Chain" AND } \\
\text { "Technology Transfer" OR “Knowledge Transfer" } \\
\text { AND "model" OR “framework" }\end{array}$ & 0 & 2 & 0 & 2 \\
\hline 11 & $\begin{array}{l}\text { "GSC" OR “Green Supply Chain" AND } \\
\text { "Innovation" OR "Green Innovation" AND } \\
\text { "Technology Transfer" OR “Knowledge Transfer" } \\
\text { AND “model" OR "framework" }\end{array}$ & 0 & 0 & 0 & 0 \\
\hline
\end{tabular}

Phase 5-Filtering procedures: were used to eliminate duplicated papers; papers not related to the theme; conference papers and books and/or book chapters. Conference papers and books or book chapters were added in another search, as complementary material.

Phase 6-Identifying impact factor, year and number of citations: the metrics of the papers (impact factor) were obtained from the Thomson's Reuters/Clarivate Analytics website. Since Journal Citation Reports (JCR) is the most common metric used, the papers will have the preference to use it. If the paper does not use JCR, the next metric will be to search on the Scopus website, following this order of preference: CiteScore, SJR (SCimago), or SNIP.

The number of citations was obtained from Google Scholar. This information-metrics and number of citations-along with the year of publication, is necessary to calculate the InOrdinatio.

Phase 7-Ranking the papers using the InOrdinatio: in order to rank the papers according to their scientific relevance, the index of ordination — the InOrdinatio Equation (1) —is applied, using an electronic spreadsheet. 


$$
\text { InOrdinatio }=(\mathrm{IF} / 1000)+\alpha \times[10-(\text { ResearchYear }- \text { PublishYear })]+(\mathrm{Ci})
$$

The elements of the equation are: IF (impact factor); $\alpha$ (alfa value, ranging from 1 to 10 , to be defined by the researcher according to the importance of the newness of the theme; for this study, the value of $\alpha$ was defined to be 10, since the theme is the object of the study in very recent papers); ResearchYear (year in which the research was developed); PublishYear (year in which the paper was published); and $\mathrm{Ci}$ (number of times the paper has been cited).

Phase 8-Finding the full papers: papers were collected and stored using the reference manager Mendeley.

Phase 9-Reading and systematizing analysis of the papers: bibliometric mapping and content analysis were used to evaluate the papers.

\subsection{The KTT-GSCM Multicriteria Model}

The systematic literature review made possible the description of the conceptual framework of the GSCM based on KTT, where three perspectives that theoretically influence one another have been identified: GSCM, KTT and Innovation. From these perspectives, 13 key factors have been identified that characterize each one of them. These key factors were listed and selected according to the following criteria: (1) papers that presented a higher InOrdinatio; (2) papers that presented a framework or model; (3) frameworks and models were studied and the most used factors among them were analyzed. From this compilation, our conceptual framework was elaborated.

Table 2 summarizes the perspective presented in the framework, factors and their descriptions, and their respective references.

Table 2. Perspectives and factors presented in the framework.

\begin{tabular}{|c|c|c|c|}
\hline PERSPECTIVES & FACTORS & DESCRIPTION & AUTHORS \\
\hline \multirow{7}{*}{ GSCM } & & Based on: SCOR Model with green factors & {$[48,50-52,130]$} \\
\hline & Green Plan & $\begin{array}{l}\text { Development of green plans to operate the SC, i.e., environmental } \\
\text { training, ISO orientations, sustainable action planning, sustainable } \\
\text { product planning. }\end{array}$ & \multirow{6}{*}{ Based on: $[48,50,51,130]$} \\
\hline & Green Source & Requesting and reception of materials and services/Green Purchasing. & \\
\hline & Green Make & $\begin{array}{l}\text { Activities related to the transformation of materials or the creation of } \\
\text { content for services, focusing on Clean Production and Sustainable } \\
\text { Products. }\end{array}$ & \\
\hline & Green Deliver & $\begin{array}{l}\text { Activities related to the creation, maintenance and fulfillment of } \\
\text { customer requests/Green Logistics. }\end{array}$ & \\
\hline & Green Return & $\begin{array}{l}\text { Activities related to the reverse flow of products, such as waste } \\
\text { management (Reducing, Reusing and Recycling Products), and Reverse } \\
\text { Logistics. }\end{array}$ & \\
\hline & Green Enable & Processes related to the support of the GSC. & \\
\hline \multirow{3}{*}{ KTT } & & Based on: Types of KTT & [131] \\
\hline & Vertical KTT & $\begin{array}{l}\text { The transfer of technological knowledge and innovation, from basic } \\
\text { to advanced research, from the R\&D phase to the commercialization } \\
\text { of the product. }\end{array}$ & \multirow{2}{*}[131,132]{} \\
\hline & Horizontal KTT & $\begin{array}{l}\text { The transfer of technological knowledge or innovation among } \\
\text { projects, organizations, industries and nations. It is considered as the } \\
\text { transfer carried out from one geographical location to another. }\end{array}$ & \\
\hline \multirow{6}{*}{ Innovation } & & Based on: Steps of Innovation & {$[61,71,72]$} \\
\hline & Knowledge & $\begin{array}{l}\text { Related to the awareness of the existence and understanding of } \\
\text { sustainability. }\end{array}$ & \multirow{5}{*}[61,71]{} \\
\hline & Decision & $\begin{array}{l}\text { The decision of whether the innovation will be adopted or rejected is } \\
\text { made. }\end{array}$ & \\
\hline & Development & $\begin{array}{l}\text { Involves operational and organizational matters that may arise when } \\
\text { putting the new idea to practice. }\end{array}$ & \\
\hline & Dissemination & $\begin{array}{l}\text { Includes raising awareness, building knowledge, and distributing } \\
\text { materials. }\end{array}$ & \\
\hline & Implementation & $\begin{array}{l}\text { Occurs when the decision maker recognizes the benefits of } \\
\text { sustainability and integrates it as an ongoing practice. }\end{array}$ & \\
\hline
\end{tabular}


This framework raised the hypotheses that the perspectives GSCM, KTT, and Innovation influence one another. In order to achieve the objective of this paper, we developed a multicriteria model containing two stages, as shown in Figure 4. This model is called the KTT-GSCM Multicriteria Model.

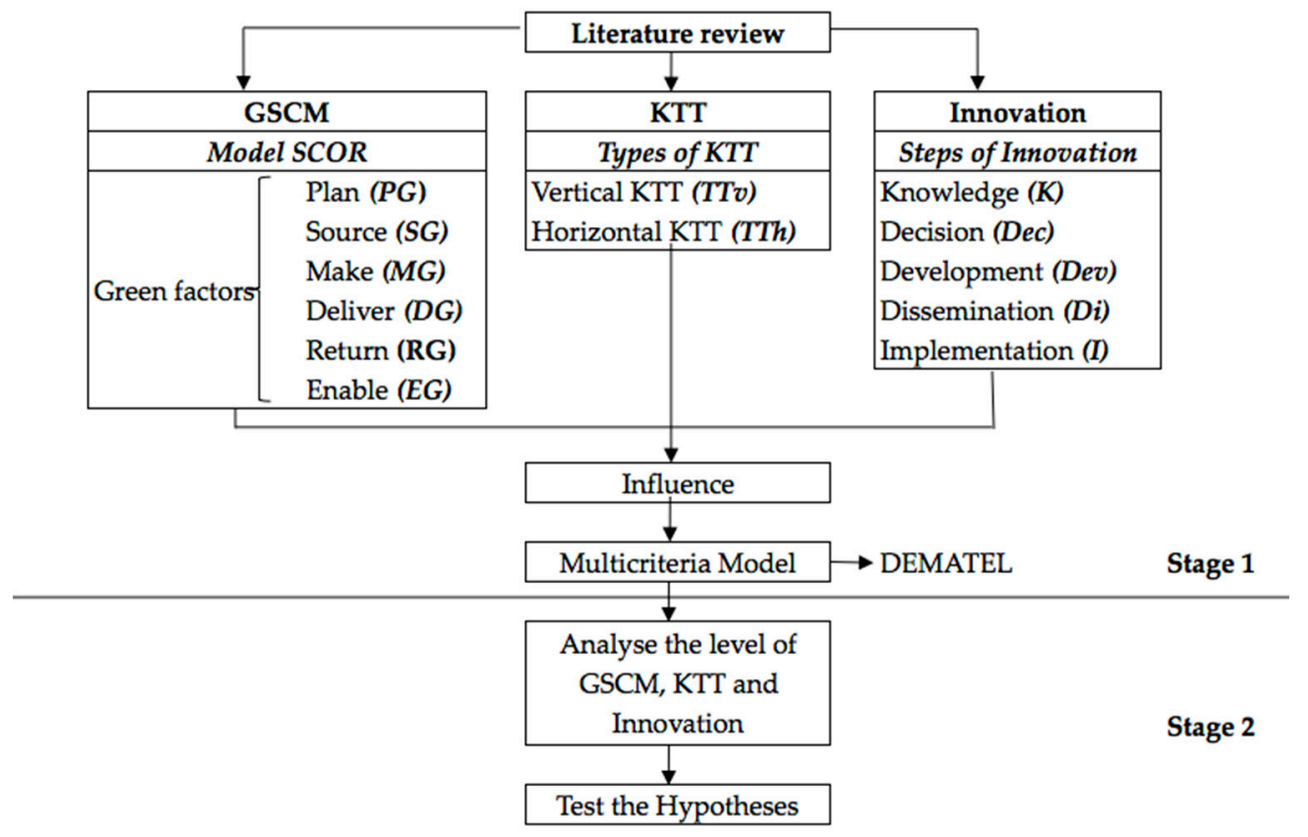

Figure 4. Stages in the development of the KTT-GSCM Multicriteria Model.

The first stage describes the factors that are relevant to GSCM, KTT, and Innovation, ascertaining which ones have influence over the others and which ones are influenced through the DEMATEL method. In addition, this stage assigns weights to those factors according to their general impact in relation to the others. (Section 3.2.2)

The DEMATEL multicriteria method was used in this model since it is the main Multicriteria Decision Analysis (MDCA) model capable of testing the influence among factors. DEMATEL is an extended method for building and analyzing a structural model for analyzing the influence relation among complex criteria [133]. According to the criteria developed by Lee et al. [134], the original DEMATEL model is feasible in this case and can be applied because each column-sum of the matrix is less than one in the normalized initial direct-relation matrix.

The second stage of the model analyzes the level of each perspective in each company and in the chain as a whole, thus verifying the hypotheses. It enables the study to compare the firms in a SC. (Section 3.2.3).

\subsubsection{The DEMATEL Method}

According to Wu and Lee [135], the Decision-Making Trial and Evaluation Laboratory (DEMATEL), developed by Gabus and Fontela [136], can be summarized as follows:

Step 1. Generates the cross-relation matrix A, expressing the level of influence that the element $i$ in the matrix row exerts over the element $j$ in the matrix column, in which $a_{i j}$ is the influence that the element $i$ have on the element $j$. To ascertain the level of influence, a scale of comparison between the levels of influence must be established using integer values from 0 to 4 , in which 0 means no influence, 1 means low influence, 2 means medium influence, 3 means high influence, and 4 means very high influence.

Step 2. Generates the direct-relation matrix D, calibrating the previous matrix according to Equation (2) and Equation (3).

$$
D=A \times s
$$


where

$$
s=\max \left(\max _{1 \leq i \leq n} \sum_{j=1}^{n} a_{i j}, \max _{i \leq j \leq n} \sum_{i=1}^{n} a_{i j}\right)^{-1}
$$

Step 3. Generates the total-relation matrix $\mathrm{T}$ according to Equation (4), where $I$ is the identity matrix and $(I-D)^{-1}$ is an inverse matrix.

$$
T=D(I-D)^{-1}
$$

Step 4. Calculates the sum of each $r i$ row of matrix $\mathrm{T}$ (Equation (5)) and the sum of each column $c i$ of matrix $\mathrm{T}$ (Equation (6)).

$$
\begin{aligned}
& r_{i}=\sum_{j=1}^{n} t_{i j} \\
& c_{i}=\sum_{i=1}^{n} t_{i j}
\end{aligned}
$$

The row sum of each $r i$ element represents the total impact of each element on the set of elements examined, whereas the column sum of each ci element represents the total impact received by each element.

In addition, the sum $r i+c i$ for each element represents its total involvement in the set, and the difference $r i-c i$, represents the net effect of each element in the set.

The DEMATEL approach classifies the components into two groups: 1) the group 'effect', in which the elements present a negative $r-c$; and 2) the group 'cause', in which the elements present a positive $r-c$. The elements in the group 'cause' (group 2), containing the factors of influence, exert more influence than they receive from the others. The elements in the group 'effect' (group 1), suffer more influence than they exert over the others in the set.

\subsubsection{First Stage of the KTT-GSCM Multicriteria Model}

Based on the influence between the factors of GSCM, KTT, and Innovation (See Table 2-Section 3.2), the following mathematical formula can be described:

$$
\begin{aligned}
& \text { MODEL = f (PG, SG, MG, DG, RG, EG, TTh, TTv, K, Dec, Dev, Di, I); } \\
& \text { PG = f (SG, MG, DG, RG, EG, TTh, TTv, K, Dec, Dev, Di, I); } \\
& \text { SG = f (PG, MG, DG, RG, EG, TTh, TTv, K, Dec, Dev, Di, I); } \\
& \text { MG = f (PG, SG, DG, RG, EG, TTh, TTv, K, Dec, Dev, Di, I); } \\
& \text { DG = f (PG, SG, MG, RG, EG, TTh, TTv, K, Dec, Dev, Di, I); } \\
& \text { RG = f (PG, SG, MG, DG, EG, TTh, TTv, K, Dec, Dev, Di, I); } \\
& \text { EG = f (PG, SG, MG, DG, RG, TTh, TTv, K, Dec, Dev, Di, I); } \\
& \text { TTh = f (PG, SG, MG, DG, RG, EG, TTv, K, Dec, Dev, Di, I); } \\
& \text { TTv = f (PG, SG, MG, DG, RG, EG, TTh, K, Dec, Dev, Di, I); } \\
& \text { K= f (PG, SG, MG, DG, RG, EG, TTh, TTv, Dec, Dev, Di, I); } \\
& \text { Dec = f (PG, SG, MG, DG, RG, EG, TTh, TTv, K, Dev, Di, I); } \\
& \text { Dev = f (PG, SG, MG, DG, RG, EG, TTh, TTv, K, Dec, Di, I); } \\
& \text { Di = f (PG, SG, MG, DG, RG, EG, TTh, TTv, K, Dec, Dev, I); } \\
& \text { I = f (PG, SG, MG, DG, RG, EG, TTh, TTv, K, Dec, Dev, Di). }
\end{aligned}
$$

where

PG = Green Plan; SG = Green Source; $\mathrm{MG}=$ Green Make; $\mathrm{DG}=$ Green Deliver; $\mathrm{RG}=$ Green Return; $\mathrm{EG}=$ Green Enable; TTh $=$ Horizontal KTT; TTv $=$ Vertical KTT; $\mathrm{K}=$ Knowledge; Dec $=$ Decision; Dev $=$ Development $; \mathrm{Di}=$ Dissemination; $\mathrm{I}=$ Implementation . 
This means that the proposed model is a function of all of the factors and that each factor is a function of the others: they are all interconnected and all depend on or hold influence over the others. To better visualize it, we developed the following model (Figure 5). Its application consists of SC experts indicating the level of influence between each factor, and then the DEMATEL method is applied.

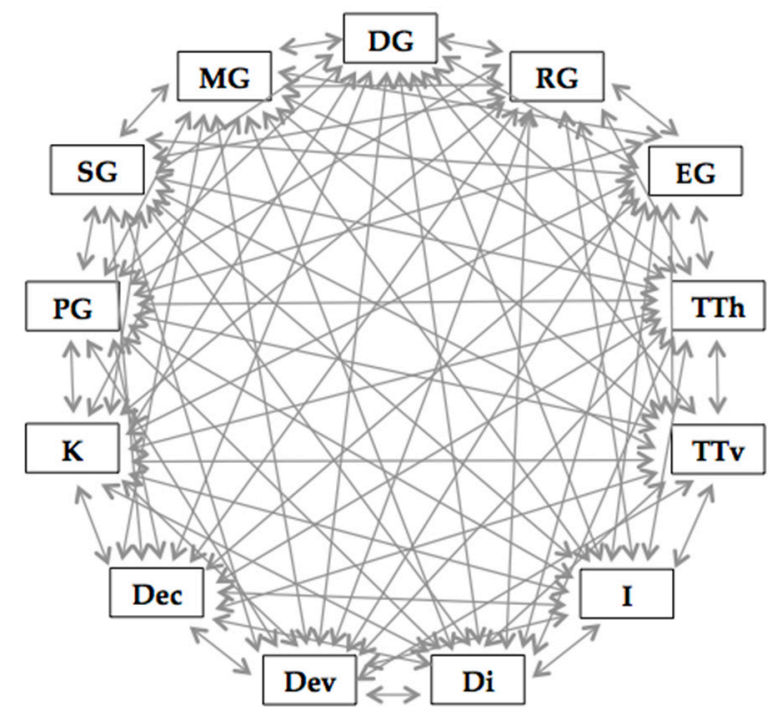

Figure 5. The model: Influence between factors of the three perspectives.

The DEMATEL method made it possible to analyze which of these factors are responsible for influencing other factors, and which ones are influenced. For each factor, a weight was assigned corresponding to its total impact on the set of factors examined.

\subsubsection{Second Stage of the KTT-GSCM Multicriteria Model}

In the second stage of the model, we elaborated a questionnaire (Table A1), in which the manager responsible for each firm in the SC answered the questions based on the factors belonging to the perspectives of GSCM, KTT, and Innovation.

The theoretical constructs used in this questionnaire, such as GSCM, KTT and Innovation, were adopted from previous research. The research instrument was pre-tested with four experts on this subject. Their feedback was used to improve the format and clarity of the survey. There is a number of questions about each factor, in a total of 22 questions for each perspective (GSCM, KTT, Innovation). All items are of perceptual measure using a 5-point Likert scale: 0 (does not occur); 1 (very rarely); 2 (occurs at small scale); 3 (occur somewhat frequently); and 4 (occurs very often/always).

After applying the questionnaires and collecting the answers, it was possible to conclude the mathematical development of the model proposed in this research. For each factor, a weight was assigned by the DEMATEL method, depending on its total impact on the set of factors ( $r i$ ). Initially, we extracted the final value of each factor individually through Equation (7).

$$
V(f)=\left(\sum_{j=1}^{n} Q\right) \times w
$$

where

$V(f)=$ final value of each factor;

$Q=$ answer to each question in each factor;

$w=$ weight assigned to the factor (ri normalized). 
It is worth mentioning that applying Equation (7) results only in the value of each factor at a single firm in the network. Therefore, the procedure must be repeated for every firm in the chain, for all of the factors, and for the 3 perspectives. Finally, the sum of all factors results in the level of each perspective at each firm, through the utilization of Equation (8).

$$
L(P)=\sum_{j=1}^{n} V(f)
$$

where

$L(P)=$ Level of each perspective;

$V(f)=$ Final value of each factor.

With the results from Equation (8), it is possible to analyze what the level of each perspective (GSCM, KTT, and Innovation) is at each of the firms and, thus, compare them in all of the firms of the $\mathrm{SC}$ to finally verify the hypotheses previously raised.

\subsubsection{Validity and Reliability of the Instrument of Measurement}

Before collecting data, this study established the internal validity of the research content through an extensive literature review, discussions with professionals and academic experts in the field, and a pre-test of the research. Each experimental group followed the same methodology to be able to correctly isolate the effect.

The data were collected through a survey sent to a SC whose focal company is a rotomolding firm (Description of that case study in Section 4). This chain features 13 supplier companies (four B2B companies, and nine B2C companies). Each company was first contacted by telephone to request their participation in the survey. For companies that volunteered to answer, appropriate respondents were requested. The questionnaire was sent by e-mail to the respondents. All the companies contacted accepted to participate in this survey, thus obtaining a 100\% response rate from this SC.

To validate the relationship between the factors and perspectives found in the theory, and used in this research instrument, a Correlation Matrix (Table 3) was performed. The discriminant validity was assessed by examining whether the mean variance extracted for items exceeded the mean shared variance (square of off-diagonal correlations) between two constructs [137]. All constructs met this criterion, indicating sufficient discriminant validity.

Table 3. Cronbach's alpha and correlation matrix.

\begin{tabular}{|c|c|c|c|c|c|c|c|c|c|c|c|c|c|c|}
\hline & 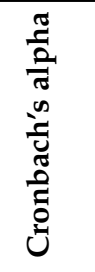 & PG & SG & MG & DG & RG & EG & TTh & $\mathbf{T T v}$ & $\mathbf{K}$ & Dec & Dev & Di & I \\
\hline PG & 0.955 & 1.000 & & & & & & & & & & & & \\
\hline SG & & 0.753 & 1.000 & & & & & & & & & & & \\
\hline MG & & 0.836 & 0.687 & 1.000 & & & & & & & & & & \\
\hline DG & & 0.924 & 0.646 & 0.639 & 1.000 & & & & & & & & & \\
\hline RG & & 0.927 & 0.800 & 0.844 & 0.821 & 1.000 & & & & & & & & \\
\hline EG & & 0.792 & 0.630 & 0.584 & 0.712 & 0.657 & 1.000 & & & & & & & \\
\hline TTh & 0.981 & 0.948 & 0.781 & 0.880 & 0.869 & 0.927 & 0.773 & 1.000 & & & & & & \\
\hline TTv & & 0.982 & 0.766 & 0.832 & 0.910 & 0.919 & 0.774 & 0.970 & 1.000 & & & & & \\
\hline $\mathbf{K}$ & 0.939 & 0.897 & 0.923 & 0.864 & 0.774 & 0.907 & 0.765 & 0.927 & 0.897 & 1.000 & & & & \\
\hline Dec & & 0.813 & 0.612 & 0.642 & 0.808 & 0.717 & 0.841 & 0.825 & 0.800 & 0.768 & 1.000 & & & \\
\hline Dev & & 0.938 & 0.819 & 0.916 & 0.823 & 0.904 & 0.735 & 0.958 & 0.943 & 0.926 & 0.784 & 1.000 & & \\
\hline Di & & 0.876 & 0.613 & 0.811 & 0.746 & 0.838 & 0.736 & 0.849 & 0.874 & 0.819 & 0.793 & 0.799 & 1.000 & \\
\hline I & & 0.908 & 0.850 & 0.769 & 0.798 & 0.889 & 0.846 & 0.894 & 0.885 & 0.945 & 0.857 & 0.857 & 0.861 & 1.000 \\
\hline
\end{tabular}


To test the reliability of the instrument, the Cronbach's alpha, shown in Table 3, was calculated. The Cronbach's alpha must exceed the generally accepted limit of 0.7 for all constructs. Therefore, the instrument showed sufficient reliability.

\section{Case Analysis}

In order to apply and test this model, the SC of a rotomolding firm that manufactures plastic products for agricultural equipment and vehicle assemblers was selected. Figure 6 displays this SC:

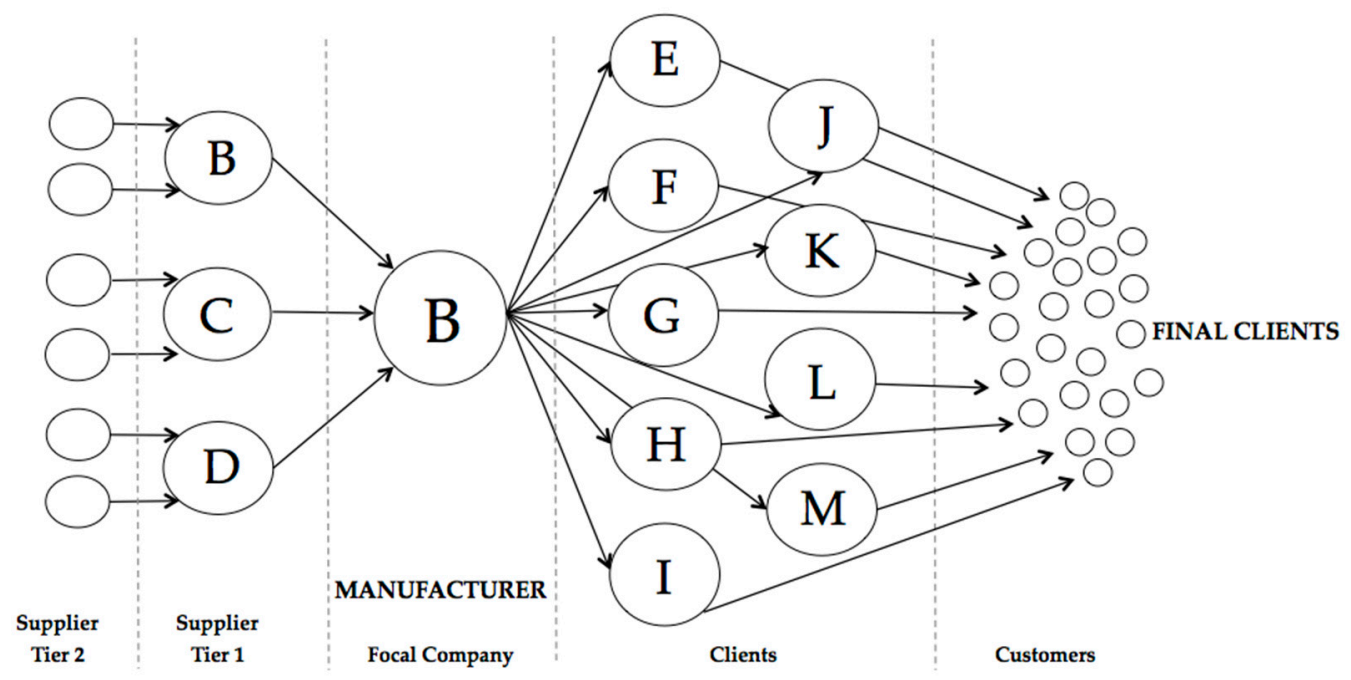

Figure 6. The SC examined.

This SC is located in the south of Brazil and was selected due to its constant search for better sustainability practices and new innovations. Its principle raw material is plastic polymers. The supplier's firms (B, C, D) receive polymers in their raw state and process them according to the market demands. At the manufacturer firm (A), our focal company in the SC, the polymer takes the shape of the product that will be attached to the final product at the equipment assembler firm. These products include tanks, ducts, protections, ceilings and others, all made out of plastic. Subsequently, the agricultural equipment and vehicle assemblers are sent to the clients (E, F, G, H, I, J, $\mathrm{K}, \mathrm{L}, \mathrm{M})$ in the SC and, then, finally sent to final clients.

For the first stage of the model, all the firms in the SC (13 firms) responded to the first questionnaire. The manager of each firm pointed out the level of influence of the factors in their SC.

For the second stage of the model, the expert managers from each of the 13 firms in the SC filled out the questionnaire containing questions about the factors and perspectives.

\section{Applying and Testing the KTT-GSCM Multicriteria Model}

\subsection{First Stage}

In order to apply the proposed model to the aforementioned SC, the following steps were followed:

Step 1. Firstly, an expert manager from each firm of the SC (13 firms) filled out a questionnaire identifying the level of influence of all of the factors in the chain, on a scale from 0 to $4: 0$ (no influence); 1 (low influence); 2 (medium influence); 3 (high influence); 4 (very high influence). Subsequently, an average of 13 responses obtained for each combination of factors was calculated. Then, the following matrix (Table 4) was generated, thus initiating the DEMATEL method. 
Table 4. Level of influence of the perspectives' factors.

\begin{tabular}{ccccccccccccccc}
\hline \multicolumn{3}{c}{ Perspectives } & \multicolumn{4}{c}{ GSCM } & \multicolumn{4}{c}{ KTT } & \multicolumn{4}{c}{ Innovation } \\
\hline \multirow{6}{*}{ Factors } & PG & SG & MG & DG & RG & EG & TTh & TTv & K & Dec & Dev & Di & I \\
\hline \multirow{4}{*}{ GSCM } & PG & 0.00 & 3.95 & 3.83 & 3.83 & 3.75 & 3.75 & 3.62 & 3.15 & 2.15 & 3.15 & 2.92 & 3.85 & 3.69 \\
& SG & 3.08 & 0.00 & 3.92 & 2.08 & 2.99 & 1.32 & 3.62 & 3.08 & 1.52 & 3.08 & 3.83 & 2.15 & 2.08 \\
& MG & 2.92 & 3.92 & 0.00 & 3.90 & 3.53 & 3.58 & 3.69 & 3.35 & 3.08 & 3.08 & 3.85 & 3.85 & 3.69 \\
& DG & 3.00 & 3.85 & 3.92 & 0.00 & 2.10 & 2.08 & 2.69 & 2.15 & 2.92 & 2.00 & 2.00 & 2.77 & 2.99 \\
& RG & 2.29 & 1.99 & 3.69 & 2.08 & 0.00 & 2.10 & 2.94 & 2.31 & 3.15 & 3.77 & 2.01 & 2.15 & 2.08 \\
& EG & 3.92 & 3.84 & 3.92 & 3.92 & 3.75 & 0.00 & 2.15 & 2.08 & 2.16 & 3.01 & 3.01 & 2.08 & 3.67 \\
KTT & TTh & 3.69 & 3.08 & 3.69 & 3.87 & 3.83 & 2.91 & 0.00 & 3.15 & 3.15 & 3.08 & 3.08 & 3.92 & 3.85 \\
& TTv & 3.38 & 2.08 & 3.85 & 2.92 & 2.89 & 3.85 & 1.12 & 0.00 & 3.88 & 3.38 & 3.62 & 3.77 & 3.46 \\
& Knnovation & 3.77 & 2.23 & 2.38 & 2.08 & 2.19 & 3.77 & 3.31 & 3.92 & 0.00 & 3.92 & 3.85 & 3.92 & 3.85 \\
& Dec & 3.77 & 1.92 & 2.92 & 1.92 & 1.98 & 3.92 & 2.53 & 1.92 & 1.87 & 0.00 & 3.92 & 3.77 & 3.62 \\
& Dev & 3.85 & 2.35 & 3.77 & 2.08 & 2.24 & 2.92 & 2.85 & 2.92 & 2.01 & 1.08 & 0.00 & 3.85 & 3.85 \\
& Di & 3.90 & 2.85 & 3.85 & 2.05 & 2.38 & 2.92 & 2.33 & 2.77 & 2.67 & 2.01 & 2.23 & 0.00 & 3.85 \\
& I & 3.77 & 3.09 & 3.69 & 3.92 & 2.38 & 2.92 & 3.77 & 3.62 & 3.69 & 2.15 & 2.00 & 2.08 & 0.00 \\
\hline
\end{tabular}

Step 2. From this initial matrix, we generated the direct-relation matrix D (Equations (2) and (3)).

Step 3. After matrix D, we generated the total-relation matrix $\mathrm{T}$ according to Equation (4). Thus, it was possible to calculate the sum of each $r i$ row in matrix $\mathrm{T}$, which represents the total impact of each element over the set, and the sum of each ci column in matrix $T$, which represents the total impact suffered by each element in the set examined.

We also calculated the sum $r i+c i$ for each factor, representing the total involvement of each element in the set, and the difference $r i-c i$, representing their net effect.

Table 5 displays the results found in the first stage of the DEMATEL method: the sum of each $r i$ row, each $c i$ column, $r i+c i$, and $r i-c i$.

Table 5. Results found by the Decision-Making Trial and Evaluation Laboratory (DEMATEL) method.

\begin{tabular}{cccccc}
\hline Perspectives & Factors & $\boldsymbol{r i}$ & $\boldsymbol{c i}$ & $\boldsymbol{r i}+\boldsymbol{c i}$ & $\boldsymbol{r i}-\boldsymbol{c i}$ \\
\hline \multirow{5}{*}{ GSCM } & PG & 6.053 & 6.024 & 12.078 & 0.029 \\
& SG & 4.867 & 5.239 & 10.106 & -0.371 \\
& MG & 6.153 & 6.330 & 12.484 & -0.177 \\
& DG & 4.839 & 5.174 & 10.014 & -0.335 \\
& EG & 4.573 & 5.056 & 9.630 & -0.483 \\
& RG & 5.486 & 5.318 & 10.804 & 0.167 \\
\hline \multirow{2}{*}{ KTT } & TTh & 6.019 & 5.150 & 11.169 & 0.869 \\
& TTv & 5.603 & 5.104 & 10.707 & 0.499 \\
\hline \multirow{5}{*}{ Innovation } & K & 5.764 & 4.790 & 10.555 & 0.974 \\
& Dec & 5.055 & 4.957 & 10.013 & 0.098 \\
& Dev & 5.043 & 5.327 & 10.370 & -0.284 \\
& Di & 5.048 & 5.593 & 10.641 & -0.545 \\
\hline
\end{tabular}

\subsection{Second Stage}

In the previous stage, we obtained the weights $(w)$ for each factor in the study to, then, initiate the second stage of the model. These weights were obtained from the normalized sum of each $r i$ row, which represents the general impact of each factor.

With the weights for each factor, the managers of the 13 firms in the SC answered the questionnaire (Appendix A). For each question, they selected a score from 0 to 4 , corresponding to 0 (does not occur); 1 (occurs very rarely); 2 (occurs on small scale); 3 (occurs somewhat frequently); and 4 (occurs very often/always).

After collecting the questionnaire responses, it was possible to conclude the mathematical development of the model proposed in this research. From Equation (7), we extracted the final value of 
each factor individually. Then, with the sum of every factor, we obtained the level of each perspective, of each firm, through Equation (8). This procedure was carried out for the 13 firms analyzed.

Thus, Table 6 presents the values found for each factor, of each firm, in addition to the total value of each perspective at each of the 13 firms.

Table 6. Values found for each factor and perspective, of each firm.

\begin{tabular}{|c|c|c|c|c|c|c|c|c|c|c|c|c|c|c|c|}
\hline \multirow{2}{*}{ Perspectives } & \multirow{2}{*}{ Factors } & \multirow{2}{*}{$w$} & \multicolumn{3}{|c|}{ Source } & \multicolumn{2}{|c|}{ Manuf. } & \multicolumn{7}{|c|}{ Client } & \multirow[b]{2}{*}{$\mathbf{M}$} \\
\hline & & & B & C & D & A & E & $F$ & $\mathrm{G}$ & $\mathbf{H}$ & I & $\mathbf{J}$ & K & L & \\
\hline \multirow{7}{*}{ GSCM } & PG & 0.086 & 0.519 & 0.692 & 0.519 & 0.865 & 1.037 & 0.951 & 1.124 & 0.951 & 0.865 & 0.865 & 1.037 & 1.037 & 1.210 \\
\hline & SG & 0.07 & 0.070 & 0.209 & 0.070 & 0.278 & 0.348 & 0.278 & 0.487 & 0.348 & 0.348 & 0.556 & 0.487 & 0.348 & 0.348 \\
\hline & MG & 0.088 & 1.143 & 0.703 & 0.967 & 1.582 & 2.021 & 1.934 & 2.109 & 1.846 & 1.582 & 1.582 & 1.846 & 1.670 & 1.758 \\
\hline & DG & 0.069 & 0.346 & 0.484 & 0.207 & 0.484 & 0.622 & 0.484 & 0.622 & 0.553 & 0.553 & 0.484 & 0.622 & 0.622 & 0.829 \\
\hline & RG & 0.065 & 0.196 & 0.261 & 0.261 & 0.392 & 0.588 & 0.523 & 0.523 & 0.523 & 0.457 & 0.523 & 0.653 & 0.523 & 0.653 \\
\hline & EG & 0.078 & 0.157 & 0.392 & 0.235 & 0.313 & 0.470 & 0.313 & 0.627 & 0.392 & 0.235 & 0.313 & 0.470 & 0.392 & 0.470 \\
\hline & \multicolumn{2}{|c|}{ TOTAL } & 2.429 & 2.740 & 2.259 & 3.914 & 5.087 & 4.482 & 5.491 & 4.612 & 4.039 & 4.323 & 5.115 & 4.591 & 5.269 \\
\hline \multirow{3}{*}{ KTT } & TTh & 0.086 & 2.493 & 2.837 & 2.063 & 3.353 & 4.385 & 3.697 & 4.213 & 4.127 & 3.353 & 3.525 & 4.299 & 3.869 & 4.213 \\
\hline & TTV & 0.08 & 0.560 & 0.560 & 0.560 & 1.521 & 1.841 & 1.521 & 1.841 & 1.681 & 1.360 & 1.360 & 1.841 & 1.761 & 2.001 \\
\hline & \multicolumn{2}{|c|}{ TOTAL } & 3.053 & 3.397 & 2.624 & 4.874 & 6.225 & 5.217 & 6.053 & 5.807 & 4.713 & 4.885 & 6.139 & 5.629 & 6.213 \\
\hline \multirow{6}{*}{ Innovation } & K & 0.082 & 1.235 & 1.400 & 1.070 & 1.811 & 2.305 & 1.976 & 2.552 & 1.976 & 1.811 & 2.305 & 2.470 & 1.976 & 2.223 \\
\hline & Dec & 0.072 & 0.361 & 0.433 & 0.289 & 0.361 & 0.505 & 0.433 & 0.578 & 0.433 & 0.433 & 0.361 & 0.578 & 0.505 & 0.505 \\
\hline & Dev & 0.072 & 0.864 & 1.008 & 0.792 & 1.513 & 2.089 & 1.657 & 2.233 & 1.945 & 1.801 & 1.657 & 1.945 & 1.873 & 1.945 \\
\hline & Di & 0.072 & 0.216 & 0.216 & 0.216 & 0.433 & 0.216 & 0.216 & 0.216 & 0.144 & 0.144 & 0.144 & 0.288 & 0.216 & 0.216 \\
\hline & I & 0.079 & 0.157 & 0.315 & 0.157 & 0.315 & 0.236 & 0.236 & 0.315 & 0.157 & 0.157 & 0.315 & 0.315 & 0.236 & 0.236 \\
\hline & \multicolumn{2}{|c|}{ TOTAL } & 2.834 & 3.372 & 2.525 & 4.432 & 5.352 & 4.518 & 5.894 & 4.656 & 4.347 & 4.782 & 5.596 & 4.807 & 5.126 \\
\hline
\end{tabular}

\section{Result Analysis and Discussion}

\subsection{First Stage - the Influence and Impact of Each Factor}

The first stage of the KTT-GSCM Multicriteria Model identified the results related to the influence of each factor as well as their weights.

Following the DEMATEL approach, we classified the elements into two groups: influenced factors, presenting a negative $r-c$, and influencing factors, presenting a positive $r-c$. The influencing factors exert more influence than they suffer within the set, whereas the influenced factors suffer more impact than they have over the other elements.

Figure 7 displays a graph representing the situation found in the model. The factors above the $\mathrm{x}$-axis $(r i+c i)$ are the ones responsible for influencing the others, while the factors below the same axis are the ones being influenced. This graph also illustrates that the higher the $r i+c i$ value (more to the right), the more the total involvement of each factor in the set. 


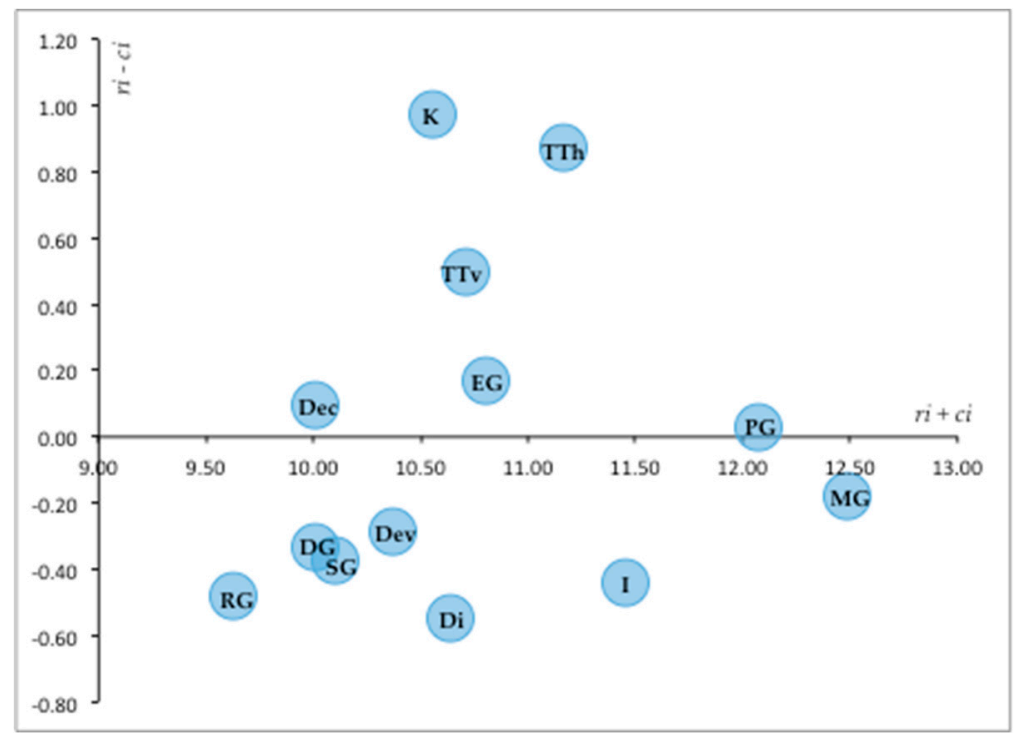

Figure 7. Influencing and influenced factors $(r i-c i)$ and the total involvement of each factor in the set $(r i+c i)$.

The factor with the greatest total involvement in the set is Make Green (MG), even though it suffers influence from others. This factor depends on the others in many aspects; however, it is the 'lung' of our system, a crucial factor for the entire chain and, as such, it presents the greatest total involvement. In order to facilitate the understanding, Table 7 displays the influencing and influenced factors.

Table 7. Influencing and influenced factors.

\begin{tabular}{lc}
\hline \multicolumn{1}{c}{ Influencing Factors } & Influenced Factors \\
\hline Knowledge (K) & Green Make (MG) \\
Horizontal Technology Transfer (TTh) & Development (Dev) \\
Vertical Technology Transfer (TTv) & Green Deliver (DG) \\
Green Enable (EG) & Source Green (SG) \\
Decision (Dec) & Implementation (I) \\
Green Plan (PG) & Return Green (RG) \\
& Dissemination (Di) \\
& Implementation (I) \\
\hline
\end{tabular}

In Figures 8 and 9, it is possible to perceive the main pairs of correlation; that is, the directions of influence present in this set. Figure 8 presents in isolation, in each of the three perspectives, the directions of influence among its factors. Figure 9 shows the directions of influence between the factors of the three perspectives. The continuous lines correspond to the highest levels of influence presented, through the DEMATEL total-relation matrix T (above 0.50). The dashed lines also correspond to high levels of influence but are smaller than those of thick lines (between 0.46 and 0.50). The thinner dotted lines correspond to small levels of influence (smaller than 0.45 ). It is possible to visualize the factors that influence and are influenced. 


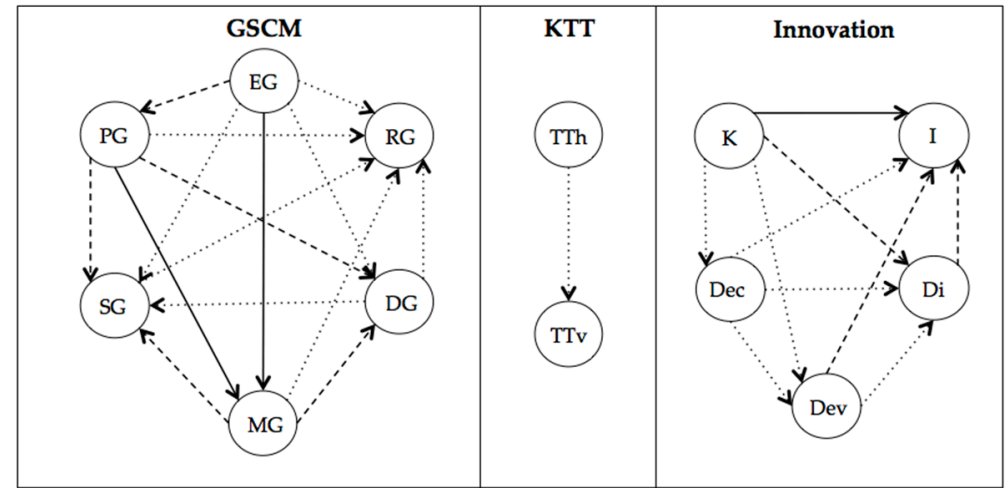

Figure 8. The directions of influence in each perspective.

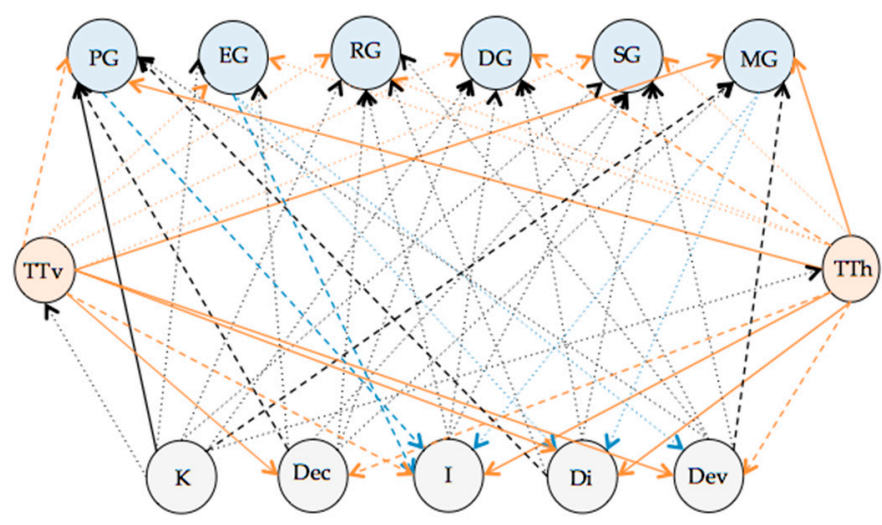

Figure 9. The directions of influence between the perspectives.

Still in the first stage, we obtained the weights of each factor in order to proceed with the model. They were ascertained through their general impact on the set of factors ( $r i$ ). Figure 10 presents a graph that expresses the impact of each factor.

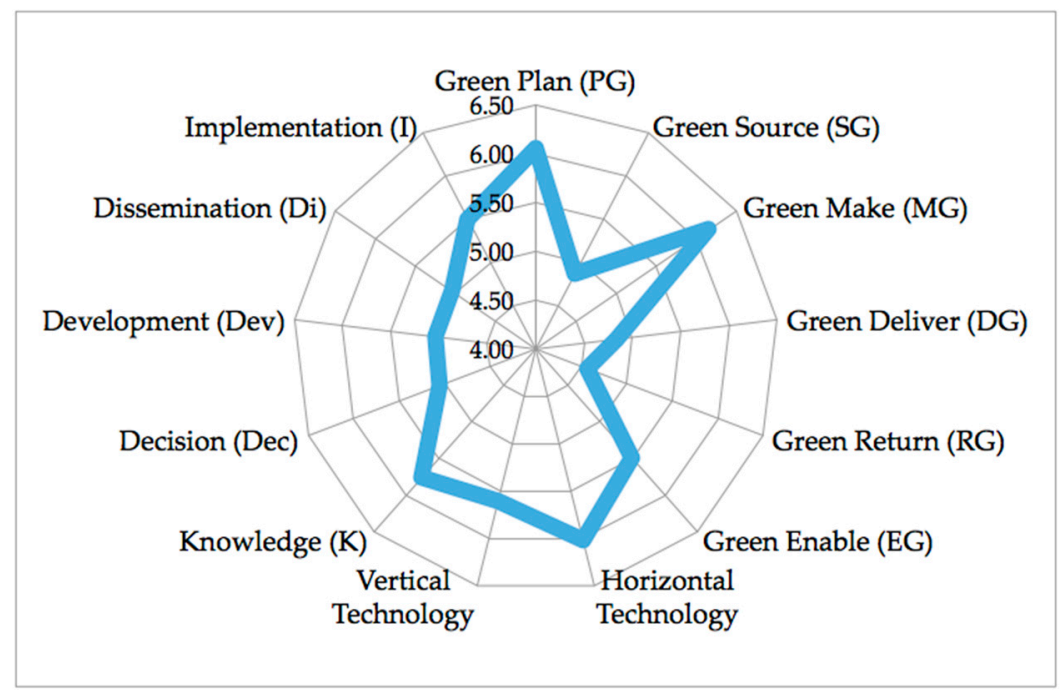

Figure 10. General impact of each factor in the chain (ri).

It is noticeable that the factors that impact the most are Green Make and Green Plan, referring to the GSCM perspective; Horizontal Technology Transfer, referring to KTT perspective; and Knowledge regarding Innovation perspective. According to the model, these factors are those that have a greater 
impact on the others, that is, decisions are often based on them. In this constructed model (KTT-GSCM Multicriteria Model), its values represent the weight of each factor.

\subsection{Second Stage— the Level of Each Perspective}

The second stage of the KTT-GSCM Multicriteria Model analyzed the level of each perspective (GSCM, TT, and Innovation) at each of the firms, which enabled us to compare the perspectives and the firms of the SC in order to, in turn, verify the hypotheses raised by the research.

Figure 11 illustrates the results of the three perspectives (GSCM, KTT, and Innovation) at each of the 13 firms examined: (a) Source-firms B, C, D, (b) Manufacturer-firm A, and (c) Client-firms E, F, G, H, I, J, K, L, M.

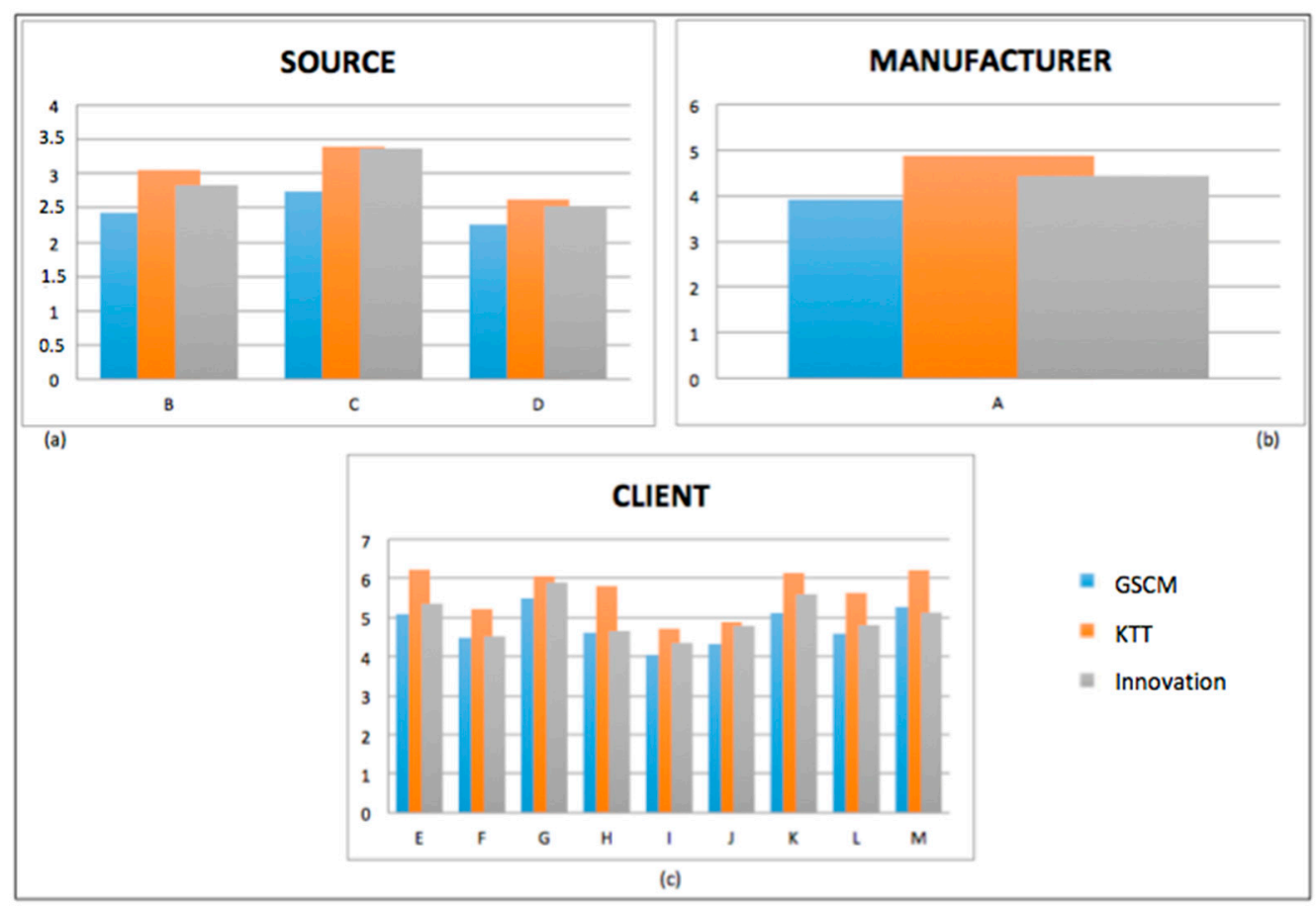

Figure 11. (a) Result of the three perspectives at the Source firms-B, C and D. (b) Result of the three perspectives at the Manufacturer firm-A. (c) Result of the three perspectives at the Clients firms-E, F, G, H, I, J, K, L and M.

Figure 12 also shows the results obtained from the three perspectives, for each company in the SC, with a different presentation, so that it is possible to compare all the companies of the SC. It is clearly noticeable that the greater the results in GSCM, the greater the results in KTT and in Innovation. A trend line for each of the perspectives is presented.

All the firms behave similarly, presenting their best results in KTT, followed by Innovation and GSCM.

When comparing the 13 firms, it is noticeable that all the Client firms (E, F, G, H, I, J, K, L, M) in the $\mathrm{SC}$ have the best performance in the three perspectives. They display a noticeable difference in relation to the Source firms (B, C, D), presenting as the most highly developed firms.

It is worth taking into account that the Client firms are larger than Source firms and Manufacturer firm, functioning at a more complex level of technology. In the example applied, we observe that the closer to the end of the SC and the larger the firm, the better it performs in the criteria KTT, Innovation, and GSCM. 


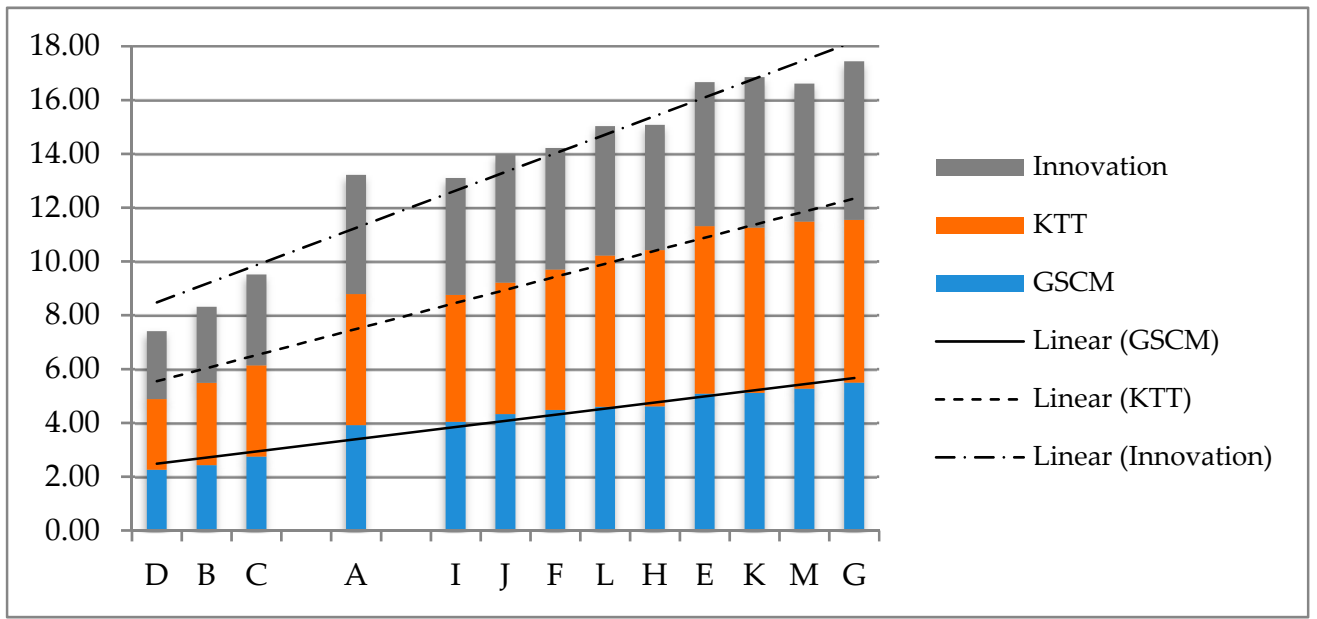

Figure 12. Results of the three perspectives in the 13 firms.

The construction of this model allowed us to verify the hypotheses raised by the conceptual framework:

H1a. Knowledge Transfer has a positive effect on GSCM performance;

H1b. Technology Transfer has a positive effect on GSCM performance:

It is possible to observe that firms with better developed Knowledge and Technology Transfer perform better in their GSC (Figures 11 and 12). The results of Figures 11 and 12 are aligned with the results of the directions of influence of the factors, shown in Figure 9. The results point out that the factors of KTT influence the factors of GSCM. Analyzing the two results obtained, and comparing with what the authors studied in the literature review [2,34,45,63,77-79,84-91], it is noticeable that Knowledge Transfer and Technology Transfer have a positive effect on GSCM performance. Moreover, Srivastava [5] recommended that further research is required on KTT or improvement and environmental performance measurement in GSCM. Thus, both hypotheses were confirmed.

H2. Innovation has a positive effect on GSCM performance:

Similar to H1a and H1b, we can see in Figures 11 and 12 that more innovative firms have higher chances of achieving higher levels of effectiveness on GSCM. In Figure 9 and Table 7, it is noticeable that Innovation is a dependent perspective, since most of its factors are influenced by the others. However, this perspective is directly influenced mainly by KTT. Analyzing Innovation in relation to GSCM, we can see that besides the fact that some factors of GSCM influence other factors of Innovation, certain factors of Innovation greatly influence factors of GSCM. The influence of the factor Knowledge on other GSCM factors is aligned with the DoI theory, where the authors say that, the diffusion of GSCM as an innovation can be viewed as a process of initiation (knowledge), persuasion, planning, adoption, and confirmation [27]. The extant literature show that Pioneer companies in green innovations profit first from the advantage [78,94]. Similarly, firms can develop innovative strategies for addressing and improving sustainability within their manufacturing processes and supply chains $[19,92,93]$. The authors show that applying innovation on GSCM can also benefit organizations in a number of ways (outcomes), which might include reducing costs, improving profits and the social image of the organization $[30,109,110]$. Analyzing the results obtained in the model, we can confirm in consonance with the literature review that Innovation has a positive effect on GSCM performance. This hypothesis was also confirmed.

H3. KTT has a positive influence in the process of Innovation in GSCM: 
Analyzing Figures 11 and 12, we can infer that the more KTT is performed by the company, the more Innovation and, consequently, better performance the company will have on the GSCM. This theory can also be confirmed by Figure 9, which shows the factors of innovation that are influenced by KTT factors. Likewise, the factors of GSCM are influenced by the factors of Innovation and KTT. The review on the extant literature proves what was obtained as a result in this model. According to the authors $[37,38]$, the success of any knowledge transfer may also be affected by the introduction of new and improved ways of performing tasks at work, which is commonly referred to as 'innovation'. Innovations occur with the support of research and development and also with KTT [23]. KTT facilitates innovation through problem definition, alternative generation and evaluation, and the ultimate choice of transferred knowledge [119]. R\&D programs and investment subsidies are the first methods introduced to improve performance and stimulate the diffusion of green technology [120]. In summary, communication, information sharing, trust and knowledge transfer, developed and consolidated through a well-structured network [122], will foster innovation. Ireland and Webb [123] provide a basis for the development of innovative solutions to environmental challenges [124] and, thus, improve the environmental performance of the supplier.

This model, corroborated by the literature review, proves that the innovation of a firm can improve its performance in GSCM practices. Successful innovations require research and development, knowledge, and materials, among other factors. Innovation requires KTT. That is to say that the more KTT in the firm, the more it innovates, and the better it performs in GSCM. These arguments answer the third hypothesis: KTT has a positive influence in the process of Innovation in GSCM.

This research, built through an exhaustive literature analysis, and reinforced by the field research and a DEMATEL application, made clear that both Innovation and KTT propel better development in GSCM, which is to say that the process of Innovation in GSCM depends on KTT.

\section{Conclusions}

The literature review revealed that the discussion on GSCM along with KTT and Innovation is inexistent, as are the frameworks and/or models related to the theme. To address this gap, we created a conceptual framework in which KTT and Innovation help to better develop a GSC. From this conceptual framework, three hypotheses arose and, to test them, we developed and proposed the KTT-GSCM Multicriteria Model, which was applied to the SC formed by 13 firms, with a rotomolding firm as the focus of the research. All the companies of the SC participated in the study.

The conceptual framework identified the existence of a mutual influence between the three perspectives analyzed: GSCM, KTT, and Innovation. For that reason, the DEMATEL method was selected to develop the first stage of the KTT-GSCM Multicriteria Model. This stage analyzed factors of the perspectives and ascertained which ones have influence over the others. The factor with the highest total involvement in the set was Make Green (MG), from the GSCM perspective. Despite its highest total involvement, this factor suffers influence; that is to say, it depends on other factors.

This first stage allowed us to conclude that the three perspectives influence one another and their factors: there are indeed interconnections between these factors and perspectives. This stage of the model is important to know which factors most influence others. An awareness of this result enables the company studied to know which factors need a priority investment. This stage also assigned weights to the factors in order to proceed with the model.

Subsequently, the second stage analyzed the level of each perspective on each of the firms in the SC in order to verify the three hypotheses previously raised. We observed that the 13 firms behaved similarly, performing better in KTT, then in Innovation and GSCM. This implies that KTT makes innovation feasible more often in a company. Therefore, innovating causes the company to present better green indices in its SC. In this second stage of the model, the companies studied can analyze and compare their performance with regards to their suppliers, customers and competitors. Thus, it is possible to perceive in which perspectives a higher investment is needed in order to obtain greater competitiveness in the market. 
Thus, all the hypotheses were confirmed with the conclusion that both Innovation and KTT propel better development in GSCM. That is to say that the process of Innovation in GSCM depends on KTT.

The developed model presented significant contributions. To the academic area, it fills a gap in the literature by exploring the interconnections between GSCM, Innovation and KTT. The literature review on the three themes helps other researchers to understand the effect that KTT and Innovation have on the performance of GSCMs. Through the investigations, it was possible to establish a synergetic relationship between GSCM, Innovation and KTT, through the conceptual framework. By quantifying and explaining the given relationships by the multicriteria model, we could analyze the influence between the perspectives, determining original conclusions for theoretical studies.

These theoretical implications and contributions are relevant to the theory of the aforementioned fields as Innovation, KTT and GSCM. These subjects have been extensively investigated but mainly treated as independent research subjects. Combining these subjects as part of the same research stream is a challenge and is original to this research.

Similarly, the practical implications and contribution of this study are equally relevant within the industrial context, especially for supply chain and operations managers who aim to gain a better understanding of the relationship and effect of contemporary operational practices on the green performance of their supply chains. In particular, the lack of a clear understanding and knowledge of the relationship between KTT and the innovation process on the performance of GSCs may create an obstacle for these managers, and their organizations to justify the implementation of GSCs.

The companies that are studied benefit from this instrument too, since it allows a broader view of the factors that influence the others, as well as how their green management, KTT and Innovation stands before their suppliers, customers and competitors.

\section{Limitations and Future Research}

This model was applied to a SC of the plastic sector, analyzing 13 firms. For future studies, the proposal is to expand the sample and perform more tests so that it can be an evolution of the proposed model. Future actions might include: (1) The application of the model to larger and more complex SCs; (2) The application of the model to SCs in different sectors, comparing the results found in each sector in order to ascertain the difference between each industrial sector; as well as to (3) To apply and perform a comparison in SCs of small and large companies; (4) Analyze the level of each TBL dimension; and (5) To apply the model in a significant number of SCs in different countries in order to compare developed and developing countries.

Limitations of the mathematical MCDM method exist. In the decision-making process, one or more equally suitable methods may exist; these require thorough understanding and appropriate use.

In addition, this model employed the DEMATEL method to analyze the influence of the perspectives and their factors. We suggest employing the fuzzy DEMATEL method; due to its qualitative data, the model may be easier to comprehend for the interviewers and interviewees, possibly resulting in different findings.

Author Contributions: Conceptualization, Pinto, M.M.; methodology, Pinto, M.M. and Pagani, R.N.; validation, Pinto, M.M; formal analysis, Pinto, M.M. and Pagani, R.N.; investigation, Pinto, M.M.; data curation, Pinto, M.M.; writing—original draft preparation, Pinto, M.M.; writing—review and editing, Pagani, R.N.; visualization, Pagani, R.N., Kovaleski, J.L. and Yoshino, R.T.; supervision, Kovaleski, J.L. and Yoshino, R.T.; project administration, Kovaleski, J.L. and Yoshino, R.T.; funding acquisition, Kovaleski, J.L.

Funding: This study was financed in part by the Coordenação de Aperfeiçoamento de Pessoal de Nível Superior-Brasil (CAPES)-Finance Code 001.

Conflicts of Interest: The authors declare no conflict of interest. 


\section{Appendix A}

Table A1. Questionnaire applied.

\begin{tabular}{|c|c|c|c|}
\hline Perspective & Factors & Questions & Authors \\
\hline \multirow{22}{*}{ GSCM } & \multirow{4}{*}{ Plan } & Is there any GSCM/sustainability training? & [79,84-87] \\
\hline & & $\begin{array}{l}\text { Is the company following the ISO orientations, conducted environmental } \\
\text { audits on a regular basis? }\end{array}$ & [1] \\
\hline & & Is there support from the superior managers of the company? & [5] \\
\hline & & Is there green production planning and scheduling? & [5] \\
\hline & \multirow[t]{2}{*}{ Source } & $\begin{array}{l}\text { The supplier meeting environmental metric criteria (with an EMS or ISO } \\
\text { 14001)? }\end{array}$ & [30] \\
\hline & & Is there any concern about green purchasing? & {$[30,58,61]$} \\
\hline & \multirow{7}{*}{ Make } & $\begin{array}{l}\text { Is there use 'end of pipeline' initiatives to lower the environmental } \\
\text { impact of production? }\end{array}$ & [5] \\
\hline & & Is there development of environmental-friendlier products? & [62] \\
\hline & & Is the waste minimized and recoverable when possible? & {$[58,63]$} \\
\hline & & Is there material recycled/reused? & {$[5,58,62]$} \\
\hline & & $\begin{array}{l}\text { Are the pollution sources minimized? (Reduce the amount of toxicity of } \\
\text { all emissions and wastes) }\end{array}$ & [5] \\
\hline & & Is there any recyclable package? & [58] \\
\hline & & Is there low consumption of water and energy? & [1] \\
\hline & \multirow{3}{*}{ Deliver } & Is there an environmental concern regarding freight transport? & [5] \\
\hline & & Is there a concern about Transportation Cost? & [57] \\
\hline & & The vehicle fuel is derived from alternative fuels? & [57] \\
\hline & \multirow{4}{*}{ Return } & Is there reuse of products? & {$[5,58]$} \\
\hline & & Is there any kind of product recycling? & {$[5,58]$} \\
\hline & & Is there remanufacturing? & {$[5,58]$} \\
\hline & & Is there adequate disposal for all products/wastes? & {$[5,58]$} \\
\hline & \multirow[t]{2}{*}{ Enable } & $\begin{array}{l}\text { There is an established green management system/green project } \\
\text { management? }\end{array}$ & {$[1,64]$} \\
\hline & & $\begin{array}{l}\text { There is provided with technical, managerial and financial assistance to } \\
\text { address environmental issues? }\end{array}$ & [64] \\
\hline \multirow{22}{*}{ KTT } & \multirow{15}{*}{ Horizontal TT } & Is there a $R \& D$ sector within the company? & {$[112,116,120]$} \\
\hline & & Are there any consultancies in the company? & [138] \\
\hline & & Is there information share between the entire chain? & {$[4,35,58]$} \\
\hline & & Is there knowledge transfer between the different sectors of the company? & [58] \\
\hline & & Is knowledge shared with suppliers? & [57] \\
\hline & & Is knowledge shared among everyone in the company? & [58] \\
\hline & & Is the knowledge shared with customers? & {$[57,58]$} \\
\hline & & Does the company feature innovations often? & {$[73,109,110]$} \\
\hline & & Does the company care about innovation? & {$[30,71,73,109,110]$} \\
\hline & & $\begin{array}{l}\text { Are there information systems, such as an integration between man and } \\
\text { machine, of quality? }\end{array}$ & {$[4,35,58]$} \\
\hline & & Are there employee training in companies? & {$[79,84-87]$} \\
\hline & & Is there organizational culture and work teams? & [64] \\
\hline & & Is there support provided from suppliers? & [57] \\
\hline & & Is there knowledge share between countries? & [24] \\
\hline & & Is there mutual trust between the organizations in the chain? & [34] \\
\hline & \multirow{7}{*}{ Vertical TT } & Is there a support from universities in the company? & [138] \\
\hline & & Are there sustainable products purchased from third parties? & [58] \\
\hline & & Is there Internship program? & [139] \\
\hline & & Is there exchange of personnel, researchers or professionals? & [140] \\
\hline & & Is there Technological Management Programs? & [64] \\
\hline & & Is there government support? & [19] \\
\hline & & Is there stakeholder support? & {$[19,108]$} \\
\hline
\end{tabular}


Table A1. Cont.

\begin{tabular}{|c|c|c|c|}
\hline Perspective & Factors & Questions & Authors \\
\hline \multirow{22}{*}{ Innovation } & \multirow{8}{*}{ Knowledge } & Is there knowledge enough for GSCM understanding? & [27] \\
\hline & & Is there an incentive for employees to generate new ideas? & [141] \\
\hline & & $\begin{array}{l}\text { Is there a joint knowledge creation? (Refers to the supply chain partners } \\
\text { jointly develop a deeper understanding of the market and corresponding } \\
\text { responses to the competitive environment) }\end{array}$ & [142] \\
\hline & & $\begin{array}{l}\text { Is there a knowledge storage? (Refers to creating a shared space, in which } \\
\text { employees can observe and learn the actions of their workmates and } \\
\text { what they can contribute to) }\end{array}$ & [143] \\
\hline & & Is there a R\&D sector inside the company? & {$[23,70,112,116,120]$} \\
\hline & & Does the company have patents? & [144] \\
\hline & & You are technologically competitive? & [33] \\
\hline & & Does the company feature innovations often? & {$[73,109,110]$} \\
\hline & \multirow{2}{*}{ Decision } & Is the company capable for change? & [27] \\
\hline & & Does the company give the aim to innovate? & {$[73,109,110]$} \\
\hline & \multirow{8}{*}{ Development } & Are the generated ideas usually put into practice? & [72] \\
\hline & & Is there innovation in process? & [72] \\
\hline & & Is there organizational innovation? & [72] \\
\hline & & Is there product innovation? & [72] \\
\hline & & The speed of new product development is fast enough/competitive? & [33] \\
\hline & & The process, techniques and technology change rapidly in our company? & [33] \\
\hline & & Is there green innovation in the company? & {$[26,78,94-97]$} \\
\hline & & Are the innovations frequent? & [72] \\
\hline & \multirow{2}{*}{ Dissemination } & Are there trainings when there is an innovation in the company? & [97] \\
\hline & & $\begin{array}{l}\text { When there is an innovation in the company, is there an awareness of its } \\
\text { importance throughout the organization? }\end{array}$ & [32] \\
\hline & \multirow{2}{*}{ Implementation } & Does continuous improvement exist in the company? & [32] \\
\hline & & $\begin{array}{l}\text { When innovations are generated in the company, is it possible to } \\
\text { recognize their benefits? }\end{array}$ & [32] \\
\hline
\end{tabular}

\section{References}

1. Green, K.; Zelbst, P.; Meacham, J.; Bhadauria, V. Green supply chain management practices: Impact on performance. Supply Chain Manag. Int. J. 2012, 17, 290-305. [CrossRef]

2. Vachon, S. Green supply chain practices and the selection of environmental technologies. Int. J. Prod. Res. 2007, 45, 4357-4379. [CrossRef]

3. Green, K.; Zelbst, P.; Bhadauria, V.; Meacham, J. Do environmental collaboration and monitoring enhance organizational performance? Ind. Manag. Data Syst. 2012, 112, 186-205. [CrossRef]

4. Sarkis, J.; Zhu, Q.; Lai, K. An organizational theoretic review of green supply chain management literature. Int. J. Prod. Econ. 2011, 130, 1-15. [CrossRef]

5. Srivastava, S. Green supply chain management: A state-of-the-art literature review. Int. J. Manag. Rev. 2007, 9, 53-80. [CrossRef]

6. Hervani, A.; Helms, M.; Sarkis, J. Performance measurement for green supply chain management. BIJ 2005, 12, 330-353. [CrossRef]

7. Wee, Y.; Quazi, H. Development and validation of critical factors of environmental management. Ind Manag. Data Syst. 2005, 105, 96-114.

8. Sheu, J.; Chou, Y.; Hu, C. An integrated logistics operational model for green-supply chain management. Transp. Res. E Log. 2005, 41, 287-313. [CrossRef]

9. Singh, R.; Acharya, P. Supply chain management: Everlasting and contemporary research issues. Int. J. Logist. Syst. Manag. 2014, 19, 1-19. [CrossRef]

10. Shi, V.; Koh, S.; Baldwin, J.; Cucchiella, F. Natural resource based green supply chain management. Supply Chain Manag. 2012, 17, 54-67.

11. Lam, H.; How, B.; Hong, B. Green supply chain toward sustainable industry development. In Assessing and Measuring Environmental Impact and Sustainability; Butterworth-Heinemann: Oxford, UK, 2015; pp. 409-449.

12. Malviya, R.; Kant, R. Modeling the enablers of green supply chain management: An integrated ISM-fuzzy MICMAC approach. BIJ 2017, 24, 536-568. [CrossRef] 
13. Mangla, S.; Kumar, P.; Barua, M. Prioritizing the responses to manage risks in green supply chain: An Indian plastic manufacturer perspective. Sustain. Prod. Consum. 2015, 1, 67-86. [CrossRef]

14. Kaiser, D.; Köhler, T.; Weith, T. Knowledge management in sustainability research projects: Concepts, effective models, and examples in a multi-stakeholder environment. Appl. Environ. Educ. Commun. 2016, 15, 4-17. [CrossRef]

15. López-Morale, V.; Ouzrout, Y.; Manakitsirisuthi, T.; Bouras, A. MKMSIS: A multi-agent knowledge management system for industrial sustainability. Stud. Comput. Intell. 2015, 607, 195-213.

16. Sujatha, R.; Krishnaveni, R. Knowledge management: An ingredient for sustainability of organizations. Int. Bus. Manag. 2015, 9, 299-309.

17. Pietrosemoli, L.; Rodríguez Monroy, C. The impact of sustainable construction and knowledge management on sustainability goals. A review of the Venezuelan renewable energy sector. Renew. Sustain. Energy Rev. 2013, 27, 683-691. [CrossRef]

18. Claro, D.; Claro, P.; Hagelaar, G. Coordinating collaborative joint efforts with suppliers: The effects of trust, transaction specific investment and information network in the Dutch flower industry. Supply Chain Manag. 2006, 11, 216-224. [CrossRef]

19. Seuring, S.; Müller, M. From a literature review to a conceptual framework for sustainable supply chain management. J. Clean. Prod. 2008, 16, 1699-1710. [CrossRef]

20. Pagell, M.; Wu, Z. Building a more complete theory of sustainable supply chain management using case studies of 10 exemplars. J. Supply Chain Manag. 2009, 45, 37-56. [CrossRef]

21. Seuring, S.; Müller, M. Core issues in sustainable supply chain management-A Delphi study. Bus. Strategy Environ. 2008, 17, 455-466. [CrossRef]

22. Akhavan, R.; Beckmann, M. A configuration of sustainable sourcing and supply management strategies. J. Purch. Supply Manag. 2016, 23, 137-151. [CrossRef]

23. Muduli, K.; Govindan, K.; Barve, A.; Geng, Y. Barriers to green supply chain management in Indian mining industries: A graph theoretic approach. J. Clean. Prod. 2013, 47, 335-344. [CrossRef]

24. Cormican, K.; O'Connor, M. Technology transfer for product life cycle extension: A model for successful implementation. Int. J. Innov. Technol. Manag. 2009, 6, 265-282. [CrossRef]

25. Battistella, C.; De Toni, A.; Pillon, R. Inter-organisational technology/knowledge transfer: A framework from critical literature review. J. Technol. Transf. 2016, 41, 1195-1234. [CrossRef]

26. Cosimato, S.; Troisi, O. Green supply chain management: Practices and tools for logistics competitiveness and sustainability. The DHL case study. TQM J. 2015, 27, 256-276. [CrossRef]

27. Zhu, Q.; Sarkis, J.; Lai, K. Green supply chain management innovation diffusion and its relationship to organizational improvement: An ecological modernization perspective. J. Eng. Technol. Manag. 2012, 29, 168-185. [CrossRef]

28. Porter, M.; Linde, C. Green and competitive. Harv. Bus. Rev. 1995, 73, 120-134.

29. Chen, Y.; Lai, S.; Wen, C. The influence of green innovation performance on corporate advantage in Taiwan. J. Bus. Ethics 2006, 67, 331-339. [CrossRef]

30. Tseng, M.; Chiu, S.; Tan, R.; Siriban-Manalang, A.B. Sustainable consumption and production for Asia: Sustainability through green design and practice. J. Clean. Prod. 2013, 40,1-5. [CrossRef]

31. Chiou, T.; Chan, H.; Lettice, F.; Chung, S. The influence of greening the suppliers and green innovation on environmental performance and competitive advantage in Taiwan. Transport. Res. E Log. 2011, 47, 822-836. [CrossRef]

32. Wu, G. The influence of green supply chain integration and environmental uncertainty on green innovation in Taiwan's IT industry. Supply Chain Manag. 2013, 18, 539-552. [CrossRef]

33. Lee, V.; Ooi, K.; Chong, A.; Seow, C. Creating technological innovation via green supply chain management: An empirical analysis. Expert Syst. Appl. 2014, 41, 6983-6994. [CrossRef]

34. Cheng, J.; Yeh, C.; Tu, C. Trust and knowledge sharing in green supply chains. Supply Chain Manag. 2008, 13, 283-295. [CrossRef]

35. Wu, G.; Cheng, Y.; Huang, S. The study of knowledge transfer and green management performance in green supply chain management. Afr. J. Bus. Manag. 2010, 4, 44-48.

36. Cao, J.; Liu, L.; Xiong, Y. Research on the Influence Mechanism of After-Sales Service Model to Remanufacturing Technology Transfer in Green Supply Chain. In Applied Mechanics and Materials; Trans Tech Publications: Zurich, Switzerland, 2014; Volume 635, pp. 1784-1788. 
37. Bandyopadhyay, S.; Pathak, P. Knowledge sharing and cooperation in outsourcing projects-A game theoretic analysis. Decis. Support. Syst. 2007, 43, 349-358. [CrossRef]

38. Liu, M.; Liu, N. Sources of knowledge acquisition and patterns of knowledge-sharing behaviors-An empirical study of Taiwanese high-tech firms. Int. J. Inform. Manag. 2008, 28, 423-432. [CrossRef]

39. Rogers, E. Diffusion of Innovations; Free Press of Glencoe: New York, NY, USA, 1962.

40. Dubickis, M.; Gaile-Sarkane, E. Perspectives on innovation and technology transfer. Procedia Soc. Behav. Sci. 2015, 213, 965-970. [CrossRef]

41. Tamer Cavusgil, S.; Calantone, R.; Zhao, Y. Tacit knowledge transfer and firm innovation capability. J. Bus. Ind. Mark. 2003, 18, 6-21. [CrossRef]

42. Tsai, W. Knowledge transfer in intraorganizational networks: Effects of network position and absorptive capacity on business unit innovation and performance. Acad. Manag. J. 2001, 44, 996-1004.

43. Gilbert, M.; Cordey-Hayes, M. Understanding the process of knowledge transfer to achieve successful technological innovation. Technovation 1996, 16, 301-312. [CrossRef]

44. Weidenfeld, A.; Williams, A.; Butler, R. Knowledge transfer and innovation among attractions. Ann. Tour. Res. 2010, 37, 604-626. [CrossRef]

45. Maurer, I.; Bartsch, V.; Ebers, M. The value of intra-organizational social capital: How it fosters knowledge transfer, innovation performance, and growth. Organ. Stud. 2011, 32, 157-185. [CrossRef]

46. Krugman, P. A model of innovation, technology transfer, and the world distribution of income. J. Polit. Econ. 1979, 87, 253-266. [CrossRef]

47. Bessant, J.; Rush, H. Building bridges for innovation: The role of consultants in technology transfer. Res. Policy 1995, 24, 97-114. [CrossRef]

48. Supply-Chain Council. Supply-Chain Operations Reference-Model-SCOR Revision 11.0; Supply-Chain Council: Chicago, IL USA, 2012.

49. Stewart, G. Supply-chain operations reference model (SCOR): The first cross-industry framework for integrated supply-chain management. Logist. Inf. Manag. 1997, 10, 62-67. [CrossRef]

50. Cheng, J.; Law, K.; Bjornsson, H.; Jones, A.; Sriram, D. Modelling and monitoring of construction supply chains. Adv. Eng. Inform. 2010, 24, 435-455. [CrossRef]

51. Schoeman, C.; Sanchez, V. Green supply chain overview and a South Africa case study. In Proceedings of the 28th Southern African Transport Conference (SATC), Pretoria, South Africa, 6-9 July 2009; pp. 569-579.

52. Ntabe, E.; LeBel, L.; Munson, A.; Santa-Eulalia, L. A systematic literature review of the supply chain operations reference (SCOR) model application with special attention to environmental issues. Int. J. Prod. Econ. 2015, 169, 310-332. [CrossRef]

53. Mangla, S.; Kumar, P.; Barua, M. Flexible decision approach for analysing performance of sustainable supply chains under risks/uncertainty. Glob. J. Flex. Syst. Manag. 2014, 15, 113-130. [CrossRef]

54. Muduli, K.; Barve, A. Sustainable development practices in mining sector: A GSCM approach. Int. J. Environ. Sustain. Dev. 2013, 12, 222-243. [CrossRef]

55. Preuss, L. Rhetoric and reality of corporate greening: A view from the supply chain management function. Bus. Strategy Environ. 2005, 14, 123-139. [CrossRef]

56. Meckenstock, J.; Barbosa-Póvoa, A.; Carvalho, A. The wicked character of sustainable supply chain management: Evidence from sustainability reports. Bus. Strategy Environ. 2015, 25, 449-477. [CrossRef]

57. Malviya, R.; Kant, R.; Gupta, A. Evaluation and selection of sustainable strategy for green supply chain management implementation. Bus. Strategy Environ. 2018, 27, 475-502. [CrossRef]

58. Kot, S. Sustainable supply chain management in small and medium enterprises. Sustainability 2018, 10, 1143. [CrossRef]

59. Ginsberg, J.; Bloom, P. Choosing the right green marketing strategy. MIT Sloan Manag. Rev. 2004, 46, 79-84.

60. Johansson, G.; Winroth, M. Lean vs. Green manufacturing: Similarities and differences. In Proceedings of the 16th International Annual EurOMA Conference, Göteborg, Sweden, 14-17 June 2009; pp. 14-17.

61. So, S.; Parker, D.; Xu, H. A conceptual framework for adopting sustainability in the supply chain. In Proceedings of the ANZAM Operations, Supply Chain and Services Management Symposium, Melbourne, Australia, 14-15 June 2012; pp. 397-413.

62. Zhang, Y.; Li, Z.; Qi, T.; Zheng, S.; Li, H.; Xu, H. Green manufacturing process of chromium compounds. Environ. Prog. 2004, 24, 44-50. [CrossRef] 
63. Rao, P. Greening the supply chain: A new initiative in South East Asia. Int. J. Oper. Prod. Manag. 2002, 22, 632-655. [CrossRef]

64. Sharma, S.; Vredenburg, H. Proactive corporate environmental strategy and the development of competitively valuable organisational capabilities. Strateg. Manag. J. 1998, 19, 729-753. [CrossRef]

65. Ślusarczyk, B. Prospects for the shared services centers development in Poland in the context of human resources availability. Pol. J. Manag. Stud. 2017, 15, 218-231. [CrossRef]

66. Kozma, T. Cooperation in the supply chain network. Forum Sci. Oecon. 2017, 5, 45-58.

67. Kemp, R.; Arundel, A.; Smith, K. Survey Indicators for Environmental Innovation. In Proceedings of the Conference Towards Environmental Innovation Systems, Garmisch-Partenkirchen, Germany, 27-29 September 2001.

68. Beise, M.; Rennings, K. Lead Markets and Regulation: A Framework for Analyzing the International Diffusion of Environmental Innovations. Ecol. Econ. 2005, 52, 5-17. [CrossRef]

69. Kusi-Sarpong, S.; Gupta, H.; Sarkis, J. A supply chain sustainability innovation framework and evaluation methodology. Int. J. Prod. Res. 2019, 57, 1990-2008. [CrossRef]

70. Zhang, F.; Gallagher, K. Innovation and technology transfer through global value chains: Evidence from China's PV industry. Energy Policy 2016, 94, 191-203. [CrossRef]

71. Addiction Technology Transfer Center (ATTC) Network Technology Transfer Workgroup. Research to practice in addiction treatment: Key terms and a field-driven model of technology transfer. J. Subst. Abuse Treat. 2011, 41, 169-178. [CrossRef]

72. Klewitz, J.; Hansen, E. Sustainability-oriented innovation of SMEs: A systematic review. J. Clean. Prod. 2014, 65, 57-75. [CrossRef]

73. Carvalho, A.; Barbieri, J. Innovation for sustainability: Overcoming the productivity of the sugar-and-ethanol Industry's conventional system. J. Technol. Manag. Innov. 2010, 5, 84-94. [CrossRef]

74. Gmelin, H.; Seuring, S. Determinants of a sustainable new product development. J. Clean. Prod. 2015, 69, 1-9. [CrossRef]

75. Kahn, K. Understanding innovation. Bus. Horiz. 2018, 61, 453-460. [CrossRef]

76. IBM. Paths to Success: Three Ways to Innovate Your Business Model; IBM Global Services: Somers, NY, USA, 2009.

77. Zhu, Q.; Sarkis, J. Relationships between operational practices and performance among early adopters of green supply chain management practices in Chinese manufacturing enterprises. J. Oper. Manag. 2004, 22, 265-289. [CrossRef]

78. Luthra, S.; Kumar, V.; Kumar, S.; Haleem, A. Barriers to implement green supply chain management in automobile industry using interpretive structural modeling technique- An Indian perspective. J. Ind. Eng. Manag. 2011, 4, 231-257. [CrossRef]

79. Ravi, V.; Shankar, R. Analysis of interactions among the barriers of reverse logistics. Int. J. Technol. Forecast. Soc. Chang. 2005, 72, 1011-1029. [CrossRef]

80. Mehrabi, J.; Gharakhani, D.; Jalalifar, S.; Rahmati, H. Barriers to Green supply chain management in the petrochemical sector. Life Sci. J. 2012, 9, 3438-3442.

81. Mathiyazhagan, K.; Govindan, K.; Haq, A.; Geng, Y. An ISM approach for the barrier analysis in implementing green supply chain management. J. Clean. Prod. 2013, 47, 283-297. [CrossRef]

82. Govindan, K.; Azevedo, S.; Carvalho, H.; Cruz-Machado, V. Impact of supply chain management practices on sustainability. J. Clean. Prod. 2014, 85, 212-225. [CrossRef]

83. Wang Chen, H.; Chou, S.; Luu, Q.; Yu, T. A fuzzy MCDM approach for Green supplier selection from the economic and environmental aspects. Math. Probl Eng. 2016, 2016, 8097386. [CrossRef]

84. Agi, M.; Nishant, R. Understanding influential factors on implementing green supply chain management practices: An interpretive structural modelling analysis. J. Environ. Manag. 2017, 188, 351-363. [CrossRef]

85. Sarkis, J.; Hasan, M.; Shankar, R. Evaluating environmentally conscious manufacturing barriers with Interpretive Structural Modeling. In Proceedings of the Environmentally Conscious Manufacturing VI, Boston, MA, USA, 1-4 October 2006.

86. Scupola, A. The adoption of internet commerce by SMEs in the South of Italy: An environmental, technological and organizational perspective. J. Glob. Inf. Technol. Manag. 2003, 6, 52-71. [CrossRef]

87. Wu, J.; Dunn, S.; Forman, H. A study on green supply chain management practices among large global corporations. J. Supply Chain Oper. Manag. 2012, 10, 182-194. 
88. Ming, K.; Ming-Lang, T.; Kim, H.; Tat, D. Knowledge management in sustainable supply chain management: Improving performance through an interpretive structural modelling approach. J. Clean. Prod. 2017, 162, 806-816.

89. Holland, C. Cooperative supply chain management: The impact of interorganizational information systems. J. Strateg. Inf. Syst. 1995, 4, 117-133. [CrossRef]

90. Dyer, J.; Singh, H. The relational view: Cooperative strategy and sources of interorganizational competitive advantage. Acad. Manag. Rev. 1998, 23, 660-679. [CrossRef]

91. Madhok, A.; Tallman, S. Resources, transactions and rents: Managing value through interfirm collaborative relationships. Organ. Sci. 1998, 9, 326-339. [CrossRef]

92. Isaksson, R.; Johansson, P.; Fischer, K. Detecting Supply Chain Innovation Potential for Sustainable Development. J. Bus. Ethics 2010, 97, 425-442. [CrossRef]

93. Cai, W.; Zhou, X. On the Drivers of Eco-Innovation: Empirical Evidence from China. J. Clean. Prod. 2014, 79, 239-248. [CrossRef]

94. Mudgal, R.; Shankar, R.; Talib, P.; Raj, T. Greening the supply chain practices: An Indian perspective of enabler's relationship. Int. J. Adv. Oper. Manag. 2009, 1, 151-176. [CrossRef]

95. Dangelico, R.; Pujari, D. Mainstreaming green product innovation: Why and how companies integrate environmental sustainability. J. Bus. Ethics 2010, 95, 471-486. [CrossRef]

96. Lee, K.; Kim, J. Integrating suppliers into green product innovation development: An empirical case study in the semiconductor industry. Bus. Strategy Environ. 2011, 20, 527-538. [CrossRef]

97. Carvalho, A.; Barbieri, J. Innovation and sustainability in the supply chain of a cosmetics company: A case study. J. Technol. Manag. Innov. 2012, 7, 144-155. [CrossRef]

98. Koh, S.; Gunasekaran, A.; Tseng, C. Cross-tier ripple and indirect effects of directives WEEE and RoHS on greening a supply chain. Int. J. Prod. Econ. 2012, 140, 305-317. [CrossRef]

99. Wong, W.; Lai, K.; Shang, K.; Lu, C.; Leung, T. Green operations and the moderating role of environmental management capability of suppliers on manufacturing firm perspective. Int. J. Prod. Econ. 2012, 140, 283-294. [CrossRef]

100. Horbach, J. Methodological Aspects of an Indicator System for Sustainable Innovation. In Indicator Systems for Sustainable Innovation; Springer: New York, NY, USA, 2005; pp. 1-19.

101. Boons, F.; Montalvo, C.; Quist, J.; Wagner, M. Sustainable Innovation, Business Models and Economic Performance: An Overview. J. Clean. Prod. 2013, 45, 1-8. [CrossRef]

102. Neutzling, D.; Land, A.; Seuring, S.; do Nascimento, L. Linking sustainability-oriented innovation to supply chain relationship integration. J. Clean. Prod. 2018, 172, 3448-3458. [CrossRef]

103. Gold, S.; Seuring, S.; Beske, P. Sustainable supply chain management and inter-organizational resources: A literature review. Corp. Soc. Responsib. Environ. Manag. 2010, 17, 230-245. [CrossRef]

104. Gimenez, C.; Tachizawa, E. Extending sustainability to suppliers: A systematic literature review. Supply Chain Manag. 2012, 17, 531-543. [CrossRef]

105. Blome, C.; Paulraj, A.; Schuetz, K. Supply chain collaboration and sustainability: A profile deviation analysis. Int. J. Oper. Prod. Manag. 2014, 34, 639-663. [CrossRef]

106. Alvarez, G.; Pilbeam, C.; Wilding, R. Nestle Nespresso AAA sustainable quality program: An investigation into the governance dynamics in a multi-stakeholder supply chain network. Supply Chain Manag. Int. J. 2010, 15, 165-182. [CrossRef]

107. Adams, R.; Jeanrenaud, S.; Bessant, J.; Denyer, D.; Overy, P. Sustainability-oriented innovation: A systematic review. Int. J. Manag. Rev. 2016, 18, 180-205. [CrossRef]

108. Ayuso, S.; Ángel Rodríguez, M.; García-Castro, R.; Ángel Ariño, M. Does Stakeholder Engagement Promote Sustainable Innovation Orientation? Ind. Mana Data Syst. 2011, 111, 1399-1417. [CrossRef]

109. Gouda, S.; Saranga, H. Sustainable Supply Chains for Supply Chain Sustainability: Impact of Sustainability Efforts on Supply Chain Risk. Int. J. Prod. Res. 2018, 56, 5820-5835. [CrossRef]

110. Aguado, S.; Alvarez, R.; Domingo, R. Model of Efficient and Sustainable Improvements in a Lean Production System Through Processes of Environmental Innovation. J. Clean. Prod. 2013, 47, 141-148. [CrossRef]

111. Organisation for Economic Cooperation and Development (OECD). The Future of Eco-Innovations: The Role of Business Models in Green Transformation; OECD: Paris, France, 2012. 
112. Vasilenko, L.; Arbačiauskas, V. Obstacles and Drivers for Sustainable Innovation Development and Implementation in Small and Medium Sized Enterprises. Environ. Res. Eng. Manag. 2012, 60, 58-66. [CrossRef]

113. Phillips, R. Technology Business Incubators: How Effective as Technology Transfer Mechanisms? Technol. Soc. 2002, 24, 299-316. [CrossRef]

114. Fu, X.; Zhang, J. Technology transfer, indigenous innovation and leapfrogging in green technology: The solar-PV industry in China and India. J. Chin. Econ. Bus. Stud. 2011, 9, 329-347. [CrossRef]

115. Lundvall, B.A.; Borrás, S. The Globalising Learning Economy: Implications for Innovation Policy; Report from DG XII, Commission of the European Union; DGXII: Brussels, Belgium, 1997; pp. 34-39.

116. Able-Thomas, U. Models of renewable energy technology transfer to developing countries. Renew Energy 1996, 9, 1104-1107. [CrossRef]

117. Grant, R. Toward a knowledge-based theory of the firm. Strateg. Manag. J. 1996, 17, 109-122. [CrossRef]

118. Strach, P.; Everett, A. Knowledge transfer within Japanese multinationals: Building a theory. J. Knowl. Manag. 2006, 10, 55-68. [CrossRef]

119. Brockman, B.; Morgan, R. The role of existing knowledge in new product innovativeness and performance. Decis. Sci. 2003, 34, 385-419. [CrossRef]

120. Menanteau, P.; Finon, D.; Lamy, M. Prices versus quantities: Choosing policies for promoting the development of renewable energy. Energy Policy 2003, 31, 799-812. [CrossRef]

121. Tariq, A.; Badir, Y.; Tariq, W.; Bhutta, U. Drivers and Consequences of Green Product and Process Innovation: A Systematic Review, Conceptual Framework, and Future Outlook. Technol. Soc. 2017, 51, 8-23. [CrossRef]

122. Krause, D.; Handfield, R.; Tyler, B. The relationships between supplier development, comminuem, social capital accumulation and perfonnance improvement. J. Oper. Manag. 2007, 25, 528-545. [CrossRef]

123. Ireland, R.; Webb, W. Strategic entrepreneurship: Creating competitive advantage through streams of innovation. Bus. Horiz. 2007, 50, 49-59. [CrossRef]

124. Parmigiani, A.; Klassen, R.; Russo, M. Efficiency meets accoumability: Performance implications of supply chain configuration, comrol, and capabilities. J. Oper. Manag. 2011, 29, 212-223. [CrossRef]

125. Pagani, R.; Kovaleski, J.; Resende, L. Methodi Ordinatio: A proposed methodology to select and rank relevant scientific papers encompassing the impact factor, number of citation, and year of publication. Scientometrics 2015, 105, 2109-2135. [CrossRef]

126. Pagani, R.N.; Kovaleski, J.L.; Resende, L.M. TICs na composição da Methodi Ordinatio: Construção de portfólio bibliográfico sobre Modelos de Transferência de Tecnologia. Ciência da Informação 2017, 46, 161-187.

127. Souza, J.T.D.; Francisco, A.C.D.; Piekarski, C.M.; Prado, G.F.D. Data Mining and Machine Learning to Promote Smart Cities: A Systematic Review from 2000 to 2018. Sustainability 2019, 11, 1077. [CrossRef]

128. Cunha, L.; Ceryno, P.; Leiras, A. Social Supply Chain Risk Management: A taxonomy, a framework and a research agenda. J. Clean. Prod. 2019, 220, 1101-1110. [CrossRef]

129. Muller, M.F.; Esmanioto, F.; Huber, N.; Loures, E.R.; Junior, O.C. A Systematic Literature Review of Interoperability in the Green Building Information Modeling Lifecycle. J. Clean. Prod. 2019, 223, 397-412. [CrossRef]

130. Putra, I.; Putra, I. Penerapan Model Green SCOR untuk Pengukuran Kinerja Green Supply Chain Management pada PT. XYZ. JIMP J. Inform. Merdeka Pasuruan 2018, 3, 97-106.

131. Ockwell, D.G.; Watson, J.; MacKerron, G.; Pal, P.; Yamin, F. Key policy considerations for facilitating low carbon technology transfer to developing countries. Energy Policy 2008, 36, 4104-4115. [CrossRef]

132. Park, S.; Lee, Y. Perspectives on Technology Transfer Strategies of Korean Companies in Point of Resource and Capability Based View. J. Technol. Manag. Innov. 2011, 6, 161-184. [CrossRef]

133. Chang, B.; Chang, C.; Wu, C. Fuzzy DEMATEL method for developing supplier selection criteria. Expert Syst. Appl. 2011, 38, 1850-1858. [CrossRef]

134. Lee, H.; Tzeng, G.; Yeih, W.; Wang, Y.; Yang, S. Revised DEMATEL: Resolving the infeasibility of DEMATEL. Appl. Math. Model. 2013, 37, 6746-6757. [CrossRef]

135. Wu, W.; Lee, Y. Developing global managers' competencies using the fuzzy DEMATEL method. Expert Syst. Appl. 2007, 32, 499-507. [CrossRef]

136. Gabus, A.; Fontela, E. World Problems, an Invitation to Further Thought within the Framework of DEMATEL; Battelle Geneva Research Centre: Switzerland, Geneva, 1972. 
137. Fornell, C.; Larcker, D. Evaluating structural equation models with unobservable variables and measurement error. J. Mark. Res. 1981, 18, 39-50. [CrossRef]

138. Lee, J.; Win, H. Technology transfer between university research centers and industry in Singapore. Technovation 2004, 24, 433-442. [CrossRef]

139. Cohen, W.; Nelson, R.; Walsh, J. Links and impacts: The influence of public research on industrial R\&D. Manag. Sci. 2002, 48, 1-23.

140. Bonaccorsi, A.; Piccaluga, A. A Theoretical Framework for the Evoluation of University-Industry Relationships. RED Manag. 1994, 24, 229-247.

141. Wambui, T.; Wangombe, J.; Muthura, M. Linking human resource management to knowledge transfer for organizational development. IJBSS 2013, 4, 169-183.

142. Malhotra, A.; Gosain, S.; Sawy, O. Absorptive capacity configurationssupply chains: Gearing for partnerenabled market knowledge creation. MIS Q. 2005, 29, 145-187. [CrossRef]

143. Van Joolingen, W.; de Jong, T.; Lazonder, A.; Savelsbergh, E.; Manlove, S. Co-Lab: Research and development of an online learning environment for collaborative scientific discovery learning. Comput. Hum. Behav. 2005, 21, 671-688. [CrossRef]

144. Gilsing, V.; Bekkers, R.; Freitas IM, B.; Van der Steen, M. Differences in technology transfer between science-based and development-based industries: Transfer mechanisms and barriers. Technovation 2011, 31, 638-647. [CrossRef]

(C) 2019 by the authors. Licensee MDPI, Basel, Switzerland. This article is an open access article distributed under the terms and conditions of the Creative Commons Attribution (CC BY) license (http://creativecommons.org/licenses/by/4.0/). 